\title{
PROMOTION OF INTEGRATED PEST MANAGEMENT (IPM) IN COWPEA PRODUCTION IN FUFORE LOCAL GOVERNMENT AREA, ADAMAWA STATE, NIGERIA
}

\author{
A. S. Haddabi ${ }^{* 1}$ \\ ${ }^{*}$ Department of Agricultural Economics and Extension, Faculty of Agriculture, Adamawa State \\ University, Mubi
}

DOI: https://doi.org/10.29121/ijetmr.v7.i6.2020.689

Article Citation: A. S. Haddabi. (2020). PROMOTION OF INTEGRATED PEST MANAGEMENT (IPM) IN COWPEA PRODUCTION IN FUFORE LOCAL GOVERNMENT AREA, ADAMAWA STATE, NIGERIA. International Journal of Engineering Technologies and Management Research, 7(6), 11-40. https://doi.org/10.29121/ijetmr.v7 .i6.2020.689

Published Date: 10 June 2020

Keywords:

Promotion

Integrated Pest Management

Cowpea

Fufore

Adamawa State

\section{ABSTRACT}

Cowpea is a good source of protein to human beings and feeds to livestock. The broad objective was the promotion of Integrated Pest Management (IPM) in cowpea production in Fufore Local Government Area, and the specific objectives were to create awareness and strengthen the farmers group, describe socio-economic characteristics of farmers, train the farmers group on IPM, compare the performance between improved variety and farmers' variety, assess profitability of IPM and demonstrate recommended IPM practices. Data collected were analysed using descriptive statistics and Gross Margin analysis. The Gross Margin under IPM practices was N200,711.80 while N6,899.60 under farmers' practice. The result of the study showed that an average yield of $239.4 \mathrm{~kg} / \mathrm{ha}$ and $1714 \mathrm{~kg} / \mathrm{ha}$ of cowpea respectively from farmers' practices and IPM practices. The participating group was strengthened in aspects of group management and to sustain the IPM practices. The farmers were trained in timely planting, correct spacing and fertilizer application, correct dose and timely application od insecticides when necessary and pests identification. $65 \%$ of the farmers agreed to adopt IPM in cowpea production as from next year (2009).

\section{INTRODUCTION}

The idea of integrated pest management (IPM) began as integrated control about 1944 in Nova Scotia, Canada and Pickett Region of California, U.S.A. (Palm et al., 1971). Credit for the origins of the integrated control concept may belong to Forbes and Woodworth (Kennedy, 1975). The basic ideas of integrated control of insect pests and use of the term goes back to the work of Smith and Allen in 1954 (Sill Jr., 1978). The name was first proposed by Barlet in California in 1956 (Palm et al., 1971).

The Pest attack on cowpea leads to low yields of grains. The peasant farmer obtains about $200-350 \mathrm{~kg} / \mathrm{ha}$ (Singh and Rachie, 1985), instead of 2.0 to 2.5 tonnes/ha grains and 2 to 3 tonnes/ha fodder under improved conditions (Singh, 2004).

Cowpea farmers rely on chemical pesticides for pest control as a single strategy. But constant use of pesticides leads to problems. These problems include: pesticide treadmill and pest resistance as occurred in Peru in 1956 whereby nearly $50 \%$ of cotton was lost after 12 applications of insecticides in the Canete valley (Palm et al., 1971); creation of secondary pests as happened in Indonesia in 1985-86 with an unprecedented outbreaks of brown plant hopper after high pesticide use (De Fliert and Winarto, 2006); health risk to people as reported by World Health

(C) 2020 The Author(s). This is an open access article distributed under the terms of the Creative Commons Attribution License, which permits unrestricted use, distribution, and reproduction in any medium, provided the original author and source are credited. 
Promotion of Integrated Pest Management (IPM) in Cowpea Production in Fufore Local Government Area, Adamawa State, Nigeria

Organization (WHO) in 2003 that an estimate of a million people were poisoned annually, with 20,000 cases resulting in death due to toxicity of the pesticides (Mathews and Baleguel, (2003). Another report by WHO in 2002 was that 3 million cases of severe pesticides poisoning which occurred each year with 220,000 fatality. International Labour Organization (ILO) (2002) revealed that 340,000 people died each year from toxic chemical poisoning at their place of work (Kolke and Kern, 2006).

Above all, highly toxic pesticides are associated with suicides, nervous system and mental health problems (Sherwood et al., 2007). To worsen the situation the chemical pesticides are costly and around 30\% of the agrochemicals marketed in developing countries do not meet international standards and the products are repeatedly applied at the wrong time, in the wrong dosages or to control the wrong pests (Schuler, 2006), and used by farmers who lacked the knowledge and proper skills in applying and handling them.

Generally, the IPM strategies applied worldwide in the management of pest populations in cowpea production are cultural, biological, physical/mechanical and chemical pest control practices.

Therefore, pest control in cowpea is best achieved through an integrated approach combining the use of insect resistant cultivars and appropriate cultural practices with minimum insecticide application (Singh and Rachie, 1985).

However, application of any one or a combination of the control measures varies from one farmer or region of the world to the other. It is in the light of the above that this research study, on promotion of IPM in cowpea production in Fufore Local Government Area of Adamawa State was carried out.

\subsection{PROBLEM STATEMENT}

Due to susceptibility and vulnerability of cowpea to pests attack throughout its geographical range, and Fufore Local Government Area in particular, low yield of cowpea grains is realized by farmers. It is possible to obtain higher yields of cowpea at less risk and cost to farmers and the environment.

Another reason for the research is prompted by appeals from cowpea farmers for a sustainable pest management strategy alternative to over reliance on chemical pesticides alone which fails to achieve the desired results, but rather create problems.

\subsection{OBJECTIVES OF THE STUDY}

The broad objective of the study is to promote integrated pest management practices in cowpea production in Fufore Local Government Area of Adamawa state.

The specific objectives are to:

1) describe socio-economic characteristics of the farmers

2) create awareness, among cowpea growers, on the existence of integrated pest management practices specifically in cowpea production and strengthen the group.

3) compare the performance of farmers' cowpea variety (Kanannado) and improved variety (Sampea-8) under IPM systems.

4) determine and compare the profitability of IPM practices in cowpea production.

5) train the farmers on integrated pest management practices in cowpea production through participatory method demonstration, criteria for pests identification and their mode of damage.

6) assess the sustainability in adoption of IPM practices in cowpea production among the trained farmers.

\subsection{JUSTIFICATION OF STUDY}

Cowpea is one of the main crops grown in the study area which provides the cheapest and the affordable source of protein to the people compared to meat, fish, eggs and milk. Cowpea is also the major source of fodder for livestock fattening in the area which constitute among the greater enterprises of the local people in the area for their livelihood.

Despite the significance of cowpea, the grains yield harvested by farmers is low due to prevalence and heavy pests attack on the crop. This necessitates a comprehensive study on IPM in cowpea production in the study area. It 
A. S. Haddabi

is believed that the findings of the study would be useful to cowpea farmers in identifying cowpea pests, stage of damage, remedy measures and application of potential IPM practices and areas of improvement in cowpea production.

Therefore the promotion of IPM in cowpea production in Fufore Local Government Area was embarked upon in order to achieve significant cowpea yields and meet up demand for the crop as good source of plant protein.

It is also expected that the study will provide an analytical framework for those currently engaged in cowpea production to determine the level of their profitability. Similarly, the study will prove invaluable to Adamawa State Ministry of Agriculture, Adamawa A.D.P. and Fufore Local Government Agricultural Department as a basis for rational and pest control policy for cowpea production. Finally it is hoped that tis work will be of assistance to researchers who will identify other areas for further studies on IPM practices in cowpea production and serve as a guide to extension workers.

\section{LITERATURE REVIEW}

\subsection{THE CONCEPT OF INTEGRATED PEST MANAGEMENT (IPM)}

Probably the standard definition for integrated pest management (IPM) was promulgated in 1966 by the United Nation Food and Agricultural organization (FAO), Rome as a pest management system that in the context of the associated environment and the population dynamics of the pest species, utilizes all suitable techniques and methods in as compatible a manner as possible, and maintains the pest populations at levels below those causing economic injury (Sill Jr., 1978).

As a result of threat posed by pests towards food production due to enormous damages, coupled with a gradual decline in success in pests control throughout the globe, there are many people, for the most part entomologists, who have urged that a new discipline be developed under the general name of pest management. This effort goes back perhaps 15years or more before the idea of pest management came up and was encouraged by a group of entomologists, primarily from the west coast of the united states (Sill Jr., 1978).

The basic ideas of integrated control of insects are well over 100 years ago. The earliest use of the control goes back to the work of Smith and Allen in 1954 (Sill Jr., 1978). Integrated control as thought of today began around 1944 in widely separated places; Nova Scotia in Canada and California in U.S.A. (Palm et al., 1971).

The name integrated control was first proposed by Barlett in California in 1956 (Palm et al., 1971). At one time the programme was being used on more than $80 \%$ of the apple and pear acreage in Nova Scotia with notable success and drastic reductions in the cost pof pest control (Palm et al., 1971).

Integrated control in California owes its origin to the successful supervised control procedures worked out for Alfalfa and Cotton in the late 1940's (Palm et al., 1971). Credit for the origin of the integrated control concept may belong to such early entomologists such as Stephen A. Forbes and C.W. Woodworth (Kennedy, 1975). Since these beginnings, the definition of integrated control has broadened considerably. Since 1967, the FAO/UNEP panel of experts on integrated pest control (Kennedy, 1975), which was exclusively an FAO panel until the early 1980's succeeded in promoting IPM among scientists as the appropriate crop protection approach of choice in developing countries.

Different pests cause great losses to crops. Approximately 6,000 species of insects are pests at times but seldom cause severe damages. Other countries throughout the world are infested with many insects pests. It is estimated that in the United States, 150-200 species or complexes of related species frequently cause serious damage. From time to time, 400-500 additional species are pests and may cause serious damage (Kennedy, 1975). There are over 185 insects associated with cowpea in Nigeria (Booker, 1965).

By 1988, there were more than 500 recorded cases of various insects and mites becoming resistant to various pesticides. It has already been observed in insects, mites, weeds, fungi and bacteria that pest organisms become resistant to certain pesticides. This must be seen as an inevitable process of biological and physiological adaptation. Today, there is hardly either a single pest or a group of pest families that have not developed resistance to a group of chemical applied over a prolonged period (Kennedy, 1975).

Integrated pest management emerged as a strategy for pest control as a result of significant change in attitude prompted by the excessive use of chemical pesticides during the 1940-1960 period in Europe and the U.S.A. This led to pesticide resistant insects, appearance of secondary pests, and the problems caused by insecticide residues, and this stimulated a renewed interest in alternative methods of pest control (Dent, 1993). In 1956, nearly 50\% of cotton 
Promotion of Integrated Pest Management (IPM) in Cowpea Production in Fufore Local Government Area, Adamawa State, Nigeria

was lost after 12 applications of insecticides in Canete Valley in Peru. Subsequently a pest management system was adopted in 1957 (Palm et al., 1971).

Furthermore, chemical sprays, apart from resistance the pests develop, marginally adds up to production Cost. Chemical sprays also pose danger as only $1 \%$ of the active ingredients reach the pest, while the remaining $99 \%$ of these substances, some of which are highly toxic, burden the environment (Daxl et al., 1994). Pesticides also threaten human health, especially users and consumers of treated food (Kennedy, 1975). Current global losses in crop production due to pests are of the order of US\$ 300 billion annually. The estimated annual cost of pesticides used in agriculture in US is $\$ 20$ billion (Rothschild, 1992). The estimated expenditure by international development agencies on pest control projects in 1988 was at least US\$150 million (Rothschild, 1992).

Cowpea (Vigna unguiculata) is a popular and nutritionally important legume crop in many parts of the tropical world (Kochhar, 1986), and is the most important source of nutritious food and fodder in West Africa (Singh, 2004). Of the total world production of 10,500,000 tonnes in 1974, about $80 \%$ comes from Nigeria alone (Kochhar, 1986), and of the world's total of about 14 million hectares area under cowpea, Nigeria has 5 million hectares (Singh, 2004), and 1.7 million tonnes (Ndiaye, 2007).

In Brazil, cowpea in the north and north-east is commonly a component of mixed cropping systems on small and medium sized farms. Its producers use low technology and rely on the interaction between components of polyculture to minimize risks (Watt and de Araujo, 1988). Adoption of cowpea specific strategies was carried out in eastern Uganda through the participatory agricultural research (PAR) activities under the auspices of the IPM collaborative research support programme (CRSP) (Erbaugh et al., 2007). The programme center of the five IPM strategies which were developed for managing the most important pests and diseases of cowpea. The strategies were: early planting, correct plant spacing and density, growing an improved cowpea variety (MU, 93), use of synthetic pesticides applied three times, and farmers to scout fields on a regular basis for destructive pests and diseases, and to spray only when pests were observed as opposed to regular calendar spraying (Erbaugh et al., 2007). Also a three- season study on IPM technologies in cowpea was also conducted in eastern Uganda for management of cowpea field pests using 10 IPM- field schools. Each school evaluated seven treatments that included farmers' practices; cowpea monoculture and cowpea/sorghum inter crop mixtures, and five varying insecticides spray regimes targeting aphids (Aphis craccivora), Flower thrips (Megalurothrips sjostedti), the legume pod borer (Maruca vitrata) and a range of pod sucking bugs. Results indicated that combining cultural practices and spraying once each at budding, flowering and podding stages was more effective and profitable with a 51\% yield grain over the farmers traditional practices (Nabirye et al., 2003).

In Kenya an experiment on the effect of cowpea resistant cultivar with ICV- 12 was used against aphids (Aphis craccivora) infestations and it shows that aphids that landed on plants of the resistant variety were not as successful due to the strong antixenosis and antibiosis resistance. The experiment also shows that the rate of spread of aphid infestations was faster in susceptible cultivar (ICV-1) plots (Annan et al., 1999). On the same vein in Kenya, research on the effect of pubescence in cowpea resistance to the legume pod borer (Maruca vitrata) was conducted using Tvnu72, Tvu946 and IT82D-716 cowpea varieties. It proves that pubescence can affect the activity of insects by chemical an mechanical means buy interfering with oviposition, attachment of eggs to plant surfaces and feeding, and ingestion (Oghiakhe, 1995).

In Nigeria, Jackai and Daoust (1986) schematically presented a model for IPM in the south-western part of Nigeria. This model relied heavily on insect resistant varieties but included cultural control (mixed-crop cowpea) and judicious use of insecticides (Singh, 1990).

A similar study was carried out in Ibadan on the use of cowpea cultivars that are resistant to Megalurothrips sjostedti and it shows failure of adults to emerge directly because of the presence of antibiosis in these cultivars which affects the population of the next generation thereby delaying the pest from reaching the economic damage threshold (Alabi et al., 2003).

Studies were conducted at the teaching and research farm of Abubakar Tafawa Balewa University, Bauchi during the 2001 and 2002 rainy seasons. Extracts of Anona reticulata seed; Anacardium occidentale (linn.) nut and Azadirachta indica (A.Juss.) seed were evaluated for their efficacy against field insect pests of cowpea. All treatments exhibited significant protection of cowpea pods and seeds from Megalurothrips sjostedti (tryp.), Maruca vitrata (Fab.) and pod - sucking bugs damage compared with the untreated control. Differences among extracts were not significant but the extracts were less effective than Lambda - cyhalothrin (Karate(R)) applied at 20g a.i./ha. A. occidentale, A. reticulata and A. indica had 32.5\%; 30.5\%; 25.5\% and 31.5\%; 29.0\%, 24.0\% pod damage in 2001 and 2002 respectively as against $78 \%$ and $66.3 \%$ pod damage in the untreated control. Synthetic insecticide showed 
A. S. Haddabi

least pod damage (16\%) and (15\%) in both years. Plant extracts gave $659-740 \mathrm{~kg} / \mathrm{ha}$ and $733-808.3 \mathrm{~kg} / \mathrm{ha}$. Higher grain yield respectively in both years while untreated plots gave $205-302 \mathrm{~kg} / \mathrm{ha}$. Yields obtained from Lambda cyhalothrin treated plots use 1191.5 and $1271.5 \mathrm{~kg} /$ ha in both years (Dungum et al., 2005).

With regards to the above, study on the effect of different intra - row spacing of cowpea on the pod - sucking bugs (Clavigralla tomentosicolis, Riptortus dentipes, Anoplocnemis curvipes and Mirperus jaculus) were conducted in Ibadan using 15,30,45 and 60 cm spacing using Ife Brown cowpea variety. Results showed that the bug populations as well as cowpea seed yield were significantly lower in $15 \mathrm{~cm}$ plot that at any other spacing but seed yield was significantly high in $30 \mathrm{~cm}$ spacing plot than in other treatment plots (Pitan and Odebiyi, 1991).

It is pertinent to appreciate the fact that cowpea is one of the most important food crops for human and livestock nutrition. Cowpea is a popular and nutritionally important legume crops in many parts of the tropical world (Singh et al., 1997). Because of this reason, FAO (1970) emphasized the importance of increasing the supply of inexpensive protein including the edible legumes or pulses of which cowpea is a chief member, for human consumption (Watt and de Araujo, 1988).

The nutritive values of cowpea consist of $24 \%$ protein and $62 \%$ soluble carbohydrates (Singh and Rachie, 1985). Others include moisture $12 \%$, fat $0.7 \%$, fibre $3.8 \%$ and ash $3.2 \%$. Therefore cowpea is the most important pulse crop in regions with low rainfall (Kochhar, 1986).

Cowpea suffers a set back as it is attacked by many insect pests throughout its geographical range, although the number and their status vary from one region to another (Singh and Allen, 1980). The pests include Aphids (Aphis craccivora), leaf hoppers (Empoasca spp. E.g. E. dolichi), Flower thrips (Megalurothrips sjostedti or Taeniothrips sjostedti), legume pod borer (Maruca vitrata), pod sucking bugs (e.g. Clavigralla spp. And Anoplocnemis curvipes,) and the storage beetle (e.g. Collosobruchus maculatus). Losses in grain or foliage attributable to cowpea field pests are from $20 \%$ to amost $100 \%$ (Singh and Rachie, 1985).

In view of the above, cowpea pest incidence and diversity dictate that a single control strategy is unlikely to produce satisfactory results. Even when chemical control strategies are used, the pests response differently to the different insecticides. As a result, the "best mix" approach is currently advocated rather than those control problems that utilize single strategies whose adhoc activities result in insect pest outbreaks.

\subsection{INTEGRATED PEST MANAGEMENT PRACTICES IN COWPEA PRODUCTION}

The following practices may be effective in eco-friendly components of pest management in cowpea:

Cultural Practices/Control: Also known as alternative control methods which includes crop rotation, fallowing, increasing plant population, hand removal of pest species, e.g. hand picking of Blister beetles, use of homemade concoctions, e.g. Neem seed Kernel extract, use of locally available bio-rational products, e.g. grow chrysanthemum spp, and use of resistant or tolerant varieties (Anonymous, 2007). Others are early planting, correct plant spacing and monitoring pests with pheromone and planting cowpea in mixtures (inter-and mix-cropping) with sorghum or maize which acts as bird perches that eat pod-borer larvae. The Natural Resources Institute (NRI) and the International Institute of Tropical Agriculture (IITA) are collaborating to develop sex pheromone traps as monitoring toolsfor Muruca vitrata (Downham et al., 2000). Trapping experiments were carried out during 1998 and 1999 within cowpea fields at the IITA research station near Cotonou, in Benin Republic. During the experiment, it was proved that more males are attracted to the trap than females (Downham et al., 2000).

Biological Control: This is the use of organism (i.e. a natural enemy) to manage or control the population of another organism. Biological pest control/management is based on the ecological principles of parasitism and predation because every organism has its natural enemies (Acquaah, 2005). The goal of ecological pest management is to manipulate various biotic factors in the production environment to maintain pest populations at levels below the economic thresholds. Some of the strategies of biological pest management are; parasitism, prey - predator relationships, structural, use of plant extracts (such as pyrethrum, nicotine, neem seed kernel extracts $5 \%$ etc.), phytoallexins, repellents (such as garlic and onion), trap plants (alternative host) e.g. crotalaria, lettuce etc, microbial sprays and installing bird perches for attracting insectivorous birds. E.g. a field research on colonization and control of Aphis craccivora by coccinellid predators in some 12 resistant and susceptible varieties was under taken in Akure in 1989 and 1990. observation shows that after artificial infestation with A. craccivora, the various cowpea where invaded by coccinellid predators during both years. Highest Aphid densities where developed in the susceptible varieties (Ofuya, 1995). 
Promotion of Integrated Pest Management (IPM) in Cowpea Production in Fufore Local Government Area, Adamawa State, Nigeria

Physical/Mechanical Pest Control/Management: This strategy involves mechanical devices or physical agents used to trap and destroy pests (Acquaah, 2005). A variety of physical and mechanical traps, handpicking, barriers (fences and traps), tillage operations; heat treatment (solarisation) and radiation; like IITA trap pheromones in Benin Republic (Anonymous, 2007).

Chemical Pest Control/Management: Chemicals used to manage pests are called pesticides. Use of chemicals (pesticides) should be as a last resort. They are designed to destroy, prevent, repel or mitigate any form of life declared to be a pest (Acquaah, 2005). Most of the pests that attack cowpea are insects. Chemical pesticides are and will continue to be of considerable importance in food production because insects are prime competitors for human food, and have innumerable species, incalculable numbers, habitat and behaviours are variable and some insects are virtually microscopic in size. They are such a significant challenge and a threat, that it is compelling to control than by every reasonable measure available (Baur, 1984). Chemical Pesticides used in controlling cowpea pests are e.g. insecticides like Karate 2.5 EC and 5 EC (lambdacyhalothrin), Multhrin 10EC, (Cypermethrin 10EC), Dizvan 1000EC (2,2 dichlorovinyl - dimethyl phosphate $1000 \mathrm{~g} / \mathrm{l})$ etc.

\subsection{DIFFUSION OF AGRICULTURAL INNOVATIONS}

Throughout sub-Saharan Africa, there is a growing consensus that inadequate systems and methods of technology transfer have limited rapid and broad-based dissemination and adoption of many improved agricultural technologies (Singh and Rachie, 1985). This has led to a search for and experimentation with alternative methods of technology designed dissemination. In the 1980s, participatory agricultural research (PAR) emerged as an attempt to enhance technology suitability and transfer by engaging farmers in the research process. Previous research in the diffusion of agricultural innovations asserts that awareness and knowledge of a new technology is a necessary first step in the adoption, decision - making process (Ogunbameru, 2001).

In practical terms, diffusion is the process by which a new idea or practice is communicated or transferred from its source or invention or development to the ultimate adopters (Ogunbameru, 2001). Diffusion begins with the actual entry of an innovation into a target system. However, the active diffusion requires a more technical approach and communication techniques in the diffusion of innovations, the process of attention, interest, desire, conviction and action are involved (Ani, 2007). The extension agents, in this wise, represents the source of information and this requires him or her to have a thorough knowledge of the farm innovation from the onset. With professionalism, the extension agent understudies the target system and thereby determines the appropriate entry point. The entry point may be an individual, a group or any other medium. The appropriateness will be determined by the following criteria (Ani, 2007): -

1) The popularity and thus representativeness among the group thereby providing legitimation for information.

2) Availability and readiness to serve in the required way

3) Personal disposition towards change in general and the technology specifically.

However, all sources of information are now accessible by everyone including the target systems. The issue of concern now then becomes information management on the part of extension service providers. This entails managing whatever information the target audience accesses and help bring out values or worthlessness of the information. The extension service providers are required to be aware of all information and help the target system sort out the area that are beneficial and that would offer the best results (Ani, 2007).

It is in view of the above that all tiers of government in Nigeria including FCT Abuja established ministries/Departments of agriculture to plan/organise agricultural policies and programmes, more especially, state governments established Agricultural Development Programmes (ADPs) to implement their extension services for effective and efficient agricultutal development. The ADPs has good network of extension deliveries in reaching the targeted farmers at all levels.

The spread of agricultural technology (diffusion) generally will be influenced by the characteristics of farmers in the community. For instance, farmers differ in their willingness to know or learn about, adopt and use fertilizers. This has been described as their level of innovativeness. This is usually affected by educational level, income status, participation in community activities etc. recognition and patronage of contact farmers and community local leaders can synergize efficient diffusion of agricultural innovations. 
A. S. Haddabi

The speed with which innovation can be spread from one place to another depends on the following general attributes;

1) The relative advantage: This is the extent to which new farm practice is assessed by farmers as superior to their present practice. The practice may be more profitable in terms of reducing drudgery or giving better yields.

2) Compatibility: This is the extent to which a recommended farm practices or innovation is seen as consistent with current and existing practices, values and past experiences of farmers.

3) Complexity: This refers to the difficulty or ease with which new farm practices and innovations can be uunderstood, learned and adopted by the farmers.

4) Trialability: This is the extent to which a new idea or technology can be adopted on a small scale for experimental purpose and observation.

5) Observability: This is the degree to which a new idea or practice is visible to farmers. If the result of the innovation cannot be demonstrated, the farmer is unlikely to be convinced.

\subsection{ADOPTION OF INNOVATIONS}

The adoption process is a mental process which an individual goes through from first hearing about a new idea to the complete and full incorporation of the idea into the total system of his behaviours. The process of adopting and using innovations among farmers is a complex one which involves a sequence of thoughts and actions (Ani, 2007).

An innovation can be a new product, equipment, skill, practice or idea related to solving identified farmers' production constraints. Innovation should therefore be seen as "changes to the status quo" which is considered to be a better solution of existing problems (Ogunbameru, 2001).

Adoption of agricultural innovations occur over a period of time in stages. The stages or steps involved in adoption process included:

1) Awareness stage: This is the stage at which the farmer learn about an idea for the first time. He merely knows that an idea exists. He does not have full information about it, its special qualities, and its potential usefulness and so on. It therefore the major task of the extension staff to bring the new idea, practice or technology to the knowledge of the farmer.

2) Interest stage: This stage entails that farmer develops interest and actively seeks further information about the innovation such as how it works and what potentialities about the innovation such as how it works and what potentialities are. The critical point at this stage is that initiative is taken by the recipient in seeking for more information.

3) Evaluation stage: At this stage the farmer show marked interest in the idea, practice or technology as it applies to them, their farm operations, or their family. Farmers evaluate how the information or new technology affects their social, economic and cultural variables. If positive, they go ahead to the next phase. If negative, they stop there. They ask such questions as: can I do it? How can I do it? Is the idea, practice or technology better than what will I get out of it? They then make mental application of the idea. They obtain more information about the idea and decide whether or not to try it.

4) Trial stage: At the trial stage, individuals have weighed the advantages and risks involved and if the idea is divisible in small segments, they will try it first on a small scale.

5) Adoption stage: This is the final adoption stage when the farmer now applies the innovation on a large scale and continues to use it in preference to old methods. The adoption stage proper is reached when the farmer makes full or optimum use of the practice and accept it as good.

\subsection{FACTORS AFFECTING ADOPTION OF INNOVATIONS}

It is a presumption that farmers will adopt any improved and proven agricultural innovation an extension staff communicates to them. Experience has shown, however, that this is far from being true (Ogunbameru, 2001). In addition to meeting the farmers' interests, needs and aspirations, the extension staff must ensure that the new innovation they introduce to the farmers meet the following conditions. 
Promotion of Integrated Pest Management (IPM) in Cowpea Production in Fufore Local Government Area, Adamawa State, Nigeria

1) The new practice, package, knowledge, technology does not increase farmers' risks. Farmers generally avert risk whenever possible. Therefore, the lesser the risk involved in the innovation, the greater its adoption by the farmers.

2) The new technology does not depart radically from the current practices of the farmers. Consequently, the innovation must be easily learned and understood by the farmers.

3) The potential gains, i.e, the cost-benefit, from the adoption of the improve technology must exceed the added costs.

4) All the needed inputs and associated services involved with the new practice or technology must be readily obtainable and affordable by the farmers.

5) The innovation must conform to the norms, values and cultures of the people.

6) There must be ready market for the produce obtained by the farmers after adopting the new technology.

7) The new practice or technology must be thoroughly tested in the target area where it is to be introduced for the following reasons:

- To ascertain that the new technology is adoptable to the local conditions.

- To instill confidence into the extension staff that the technology will work in the local environment and that it has some relative advantage over the existing farmers' practice.

- To arouse farmers' interest and extension workers' credibility. Essentially, the technology must be appropriate, relavant, affordable and within the absorption and managerial capacity of the individual ultimate users.

The new technology or package will be likely accepted if it meets existing personality needs and drives; it it is in harmony with group norms and loyalties; and if the source is perceived as trust worthy or as an expert (Ogunbameru, 2001).

\subsection{SOURCES OF TECHNICAL INFORMATION}

Rural people, particularly farmers obtain information from many sources. The sources are generally categorized into four, namely; mass media, Government agencies, neighbours and friends and commercial sources.

Research has shown that sources most by farmers vary with the stages in the adoption of diffusion process as indicated below:

1) Mass Media: are most important in creating awareness and interest. The mass media include radio, television, newspapers etc. Radio plays an important role in all the five stages of the adoption process. It reinforces the determination of listener.

2) Friends and Nighbours: are first important in the evaluation, trial and adoption stages. Similarly friends and neighbours rank second as important source for awareness and interest.

3) Commercial Sources: The use of satellite, video and computer technologies are very expensive but effective in providing farmers with on-line access to relevant agricultural information from established database or to agricultural specialists responding to transmitted questions via telephone line.

Presently, both the extension services and other service providers and their clients are experimenting with newer digital opportunities that can be effectively used to exchange, process, manage and communicate information (Ani, 2007). New prints also play a significant role under commercial dispensation.

4) Government agencies: such as ministries and departments of agriculture, ADPs, Universities, Colleges and Research Centres and Extension Agencies etc. are also important source of information at evaluation, trial and adoption stages.

\section{METHODOLOGY}

\subsection{THE SUPERVISED ENTERPRISE/EXPERIENCED PROJECT (SEP)}

The SEP is an action research which directly involves the student researcher and participating farmers which makes it significantly different from the conventional project. The action research is a farm educational process 
A. S. Haddabi

carried out through method demonstration which brings about an improvement in pest management practices to the participating farmers group in the community, and at the same time increasing the understanding about extension approach and attitude and the student to the client and vice versa.

\subsection{STUDY AREA}

Fufore Local Government is one of the 21 Local Government Areas of Adamawa State. Fufore LGA was created in 1976 and it is one of the largest LGAs of the State. Fufore, is the headquarters of Fufore Local Government, and $26 \mathrm{~km}$ away from Yola, the capital of Adamawa State. Fufore is situated South-East of Girei, and lies between latitude 9013" N and longitude 1203" (Fig. 1).

According to 2006 population census, Fufore LGA has a population of 207,288 people. The LGA shares international boundary with the Cameroon Republic in the east. It is blessed with River Benue which takes its course from the Cameroon Republic and passes through the LGA. The river has fairly large tributaries with some few of them being seasonal rivers or streams.

Mountains and hills are common features of the LGA's landscape. The vast area of valleys also encourage arable crops farming and livestock husbandry.

The major occupation of the people is farming (which include crop production, livestock husbandry, vegetables/irrigation farming and fishing). Crops such as maize, sorghum, millet, groundnuts, Bambara groundnut, cowpea, root crops, tuber crops and tree crops are grown. Local trading such as crop processing, cattle and small ruminants trading to a lesser extent also form their occupation.

There are some few tribes found in the LGA, and include Batta, Fulani, Hausa, Verre, Chamba, Kanuri, Laka and a few others. Fulfulde (Fulani language) is the most widely spoken language followed by Hausa.

The climatic pattern and vegetation zone of the area broadly varies due to the influence of the meteorological factors which change from season to season. The LGA is located within the northern Guinea Savanna zone (Fig. 2). The average annual rainfall recorded in the area is between $750-1000 \mathrm{~mm}$. The rainy season starts from April and end in October. The rainfall in this area is monomodal (Fig. 3). The temperature varies with warm day time and cool night time temperatures. The temperature is warmer between the months of March to June. The mean annual temperature varies between 300c-420c.

Humidity increases during rainy season and decreases during the dry season to a lower level. It also declines considerably during drought period in the rainy season. Its fluctuation couple with variation of temperature encourages pest population densities. Mean annual relative humidity of $70 \%$ is recorded in the area.

In the case of wind the north-east trade wind blows from north to south and is characterized by being dry and dusty. The wind sometimes leads to lodging of tall crops. The wind carries harmattan between the months of November to March and sometimes extending to early May.

The LGA is known to be endowed with abundant sunshine. Even though more radiation is received during summers that are of potential advantage for the production of various crops in the area.

The soil of the area varies in texture and range from silt, sand and clay. There is also some variation in fertility. The soil in the upland areas is sandy loam which favours production of staple crops. The bottom land soils are characterized by being silty. The soils favours the growth of tuber crops and upland rice. In the marshy area in the valleys and flooded areas, large deposits of clay soils are bound. These soils favour large production of rice as well as vegetables under irrigation.

\subsection{CREATING AWARENESS}

A date was fixed to convene a meeting between the block officer and his sub-ordinates, farmers and the student researcher. It was agreed during the meeting to form a core farmers group who are willing to participate in the SEP programme activities on IPM practices in cowpea production. The group was sensitized through discussion and interaction during the meeting, and later strengthened by trainings and demonstrations on IPM practices for effective implementation and to be efficient in skills and knowledge of the study to ensure success and sustainability of the approach.

Later a date was further slated to meet with the community and opinion leaders, block officer in charge of the area and farmers for formal introduction of the research approach to the community. On the day of the meeting, the student researcher and the block officer explained the objective of the SEP programme to the community. The 
Promotion of Integrated Pest Management (IPM) in Cowpea Production in Fufore Local Government Area, Adamawa State, Nigeria

community leaders and farmers expressed their appreciation and welcomed the idea for bringing such an innovative technology of IPM in cowpea production.

\subsection{TECHNIQUES USED IN STRENGTHENING THE PARTICIPATING FARMERS' GROUP TO SUSTAIN IPM}

The group was taught on significant measures that are inevitable in making a group great and strong. These measures are:

1) Group management through good leadership

2) Regular attendance of meetings

3) Prompt payment of monthly dues and levies

4) Good record keeping

5) Modalities for obtaining farming loan from banks

6) Inputs acquisition from accredited and reliable sources

7) Be time conscious in farming and group activities

8) Unity and cooperation among members

\subsection{TRAINING AND DEMONSTRATIONS}

The recommended agronomic and IPM practices were imparted and demonstrated to the participating farmers, and farmers also displayed the few of the practices they knew.

Below are areas of activities the training and demonstrations were carried out:

- Land/seed bed preparation

- $\quad$ Planting depth and spacing

- Seed rate

- Fertilizer requirements, rate, application methods and time of application

- Appropriate weeding

- Identification of pests and pest infested stands

- Appropriate measurers in pest management

- Identification of pesticides/insecticides and proper use of pesticides when necessary

- Compare yield from different treatment plots

- To encourage insectivorous birds (predators) in scouting for pests.

\subsection{SAMPLE SIZE}

A core-group of 20 cowpea farmers were selected to participate in the project and all were men but irrespective of specific age limit. The farmers were trained on IPM practices in cowpea production. The demonstration plots serves as contact point for discussion and technical demonstration at least once a week.

\subsection{RESEARCH DESIGN}

The project study was an action research which involved farmers and the student researcher, i.e. participatory study. Farmers were directly involved in all phases of the project from planning to evaluation of results. The core target group did not only actively participate in the project but also acted as co-researchers. The study also brought a change in the pattern of pests management in cowpea production and increased the understanding of the farmers and the student. Method demonstration was used to achieve the project objectives.

The project was preceded by a meeting with the core target group during which the plan for implementation was discussed and farmers were sensitized about IPM approach in cowpea production and they agreed upon. The farmers volunteered a land measuring 2 ha for the establishment of a study experimental plot. The land was lined out into 20 equal size plots each measuring $19.5 \mathrm{~m} \times 40 \mathrm{~m}$ as farmers treatment plots, and at the side of each of the farmers plots, a $5 \mathrm{~m} \times 5 \mathrm{~m}$ plots was lined out and used by the student researcher as his treatment plots. 


\subsection{SAMPLING PROCEDURE}

A. S. Haddabi

Purposive sampling was used to select the 20 core farmers. This was because only cowpea growers within Fufore community who were interested participated in the project.

The 20 farmers were divided into 4 categories, and each category comprised of 5 farmers for convenience of carrying out the research study.

Category one planted farmers variety (Kanannado) sole crop, category two planted improved variety (Sampea8) sole crop, category three planted improved variety intercropped with local short sorghum and category four planted farmers variety intercropped with local short sorghum.

Selection of farmers to a category of practice was based on the consensus among the farmers group. Each of the farmers was responsible for agronomic and cultural operations, practising the IPM strategies in managing their plots with guidance from the block officer, student researcher and field supervisor attached by the A.D.P. headquarters. The farmers were trained on the various IPM strategies in cowpea production.

The pattern of distribution of farmers into treatment categories is illustrated below:

Treatment 1: $\quad$ Sole crop cowpea with farmers' variety "kanannado" (5 farmers, designated plots 1-5)

Treatment 2: $\quad$ Sole crop cowpea with improved variety "sampea-8" (5 farmers designated plots 6-10)

Treatment 3: $\quad$ Improved cowpea variety (sampea-8) intercropped with sorghum (5 farmers designated plots 11-15)

Treatment 4: $\quad$ Farmers' variety (Kanannado) intercropped with sorghum (5 farmers designated plots 1620)

\subsection{DATA COLLECTION}

Data was collected after every 3 days i.e. twice a week. The methods of data collection used during the research study are the following techniques:

- Focus group discussions with the participating farmers

- Verbal interview schedules

- Collective field observation with the participating farmers.

\subsection{DATA ANALYSIS}

The data collected were analysed statistically using descriptive statistics such as mean and percentage. Relevant tables were used for fata presentation to explain important findings.

\subsection{EVALUATION OF THE PROJECT}

The following criteria were used by the student researcher and the farmers in evaluating the project:-

1) The number of farmers volunteered to participate in the research

2) The impact of the project on farmers group

3) The number of participating farmers in the group ready adopt integrated pest management practices in cowpea production in the next cropping season.

\subsection{SCHEDULE OF ACTIVITIES}

The various activities involved in carrying out the research was undertaken as presented below. March 2008

- Mobilization and interaction with farmers to ascertain their level of awareness on IPM cowpea production.

- $\quad$ Conduct of meeting with A.D.P. extension staff and the farmers group

- Identification of site for the research study

June 2008

- Site clearance of the research farm

- Procurement of inputs

International Journal of Engineering Technologies and Management Research 
Promotion of Integrated Pest Management (IPM) in Cowpea Production in Fufore Local Government Area,

- Measurements of the research farm

Adamawa State, Nigeria

- Collection of socio-economic and demographic data of the participating farmers

- Sensitizing farmers on IPM in cowpea production

August 2008

- Land preparation (ploughing) using tractor

- Lining out of the field into plots (19.5m x $40 \mathrm{~m}$ for farmers and $5 \mathrm{~m} \times 5 \mathrm{~m}$ for student researcher).

- Planting of plots by farmers and student researcher

- Commencement of data collection

September 2008

- Thinning and supply

- First weeding

- Application of fertilizers

- Commencement of second weeding

- Observation of reproductive growth of the crops

- Scouting and observation for insect pests.

October 2008

- Data collection on agronomic practices, biological interactions, stages of crops growth and spray of insecticides.

- Identification of pests, infested stands and remedy measures to pests attack.

- Assessing effects of insecticides

Generally the IPM field practices and agronomic practices carried out in cowpea production during the project research study is expressed below:-

- Dressing of seeds with seed dressing chemicals (Dressforce 42WS and General 35DS) at $10 \mathrm{~g} / 5 \mathrm{~kg}$ of seeds

- Planting of plots by farmers and student researcher between 31st August- 6th September, 2008, planting is done lately because of the short drought spell which occurred between end of July and end of August. 3 seeds/ hole was planted later thinned) to two, $88 \%$ germination was achieved.

- First weeding was carried out between 20th - 27th September, 2008, second weeding was done between 3rd - 5th October.

- Weeding is done manually whereby pests formation process were exposed to harsh environmental conditions and predators. Also weeds that serve as alternative hosts to the pests were removed.

- Fertilizer application: only $20 \%$ of the farmers applied fertilizer and such application was not effective because rains ceases earlier than normal when applied.

- Infested stands are identified, removed and buried instantly.

- Predator birds (i.e. insectivorous birds) that lands on sorghum talks are left unscarred to scout and feed on insect pests.

- Larger insect pests such as foliage beetle, striped foliage beetles, moths, blister beetles, pod sucking bugs and grass hoppers were identified, picked and killed, while aphids, thrips and leafhoppers were scouted for and sprayed with insecticides.

- Assorted insecticides were variously applied by both the participating farmers and the student researcher. The pesticides applied was to supplement the biological, agronomic and cultural practices in reduction of pests population.

It should be noted that $20 \%$ of the farmers did not apply pesticide. This is because of late planting due to drought spell which creates scepticism in their minds.

Details of insecticidal sprays and weeding is outlined in the table 3.1 and 3.2 below:- 
A. S. Haddabi

Table 3.1: Details of insecticide types and number of spray applications and manual weeding on farmers' plots

\begin{tabular}{|c|c|c|c|c|c|c|c|c|}
\hline \multirow{2}{*}{\begin{tabular}{|c|} 
Plot No. \\
Sole cowpea
\end{tabular}} & \multirow{2}{*}{$\begin{array}{c}\text { Total No. } \\
\text { of Spray } \\
\text { applicatio } \\
\text { n }\end{array}$} & \multicolumn{7}{|c|}{ Number of Applications and type of insecticides used } \\
\hline & & $1^{\text {st }}$ Spraying & $\begin{array}{c}\text { Rate/h } \\
\text { a (ml) }\end{array}$ & $2^{\text {nd }}$ Spraying & $\begin{array}{c}\text { Rate/h } \\
\text { a (ml) }\end{array}$ & $\begin{array}{c}3^{\text {rd }} \\
\text { Spraying }\end{array}$ & $\begin{array}{c}\text { Rate/h } \\
\text { a (ml) }\end{array}$ & $\begin{array}{c}\text { No. of } \\
\text { weedin } \\
\mathrm{g} \\
\end{array}$ \\
\hline 1 & 1 & Cyperforce & 1000 & - & - & - & - & 2 \\
\hline 2 & 0 & - & & - & - & - & - & 1 \\
\hline 3 & 0 & - & & - & - & - & - & 2 \\
\hline \multirow[t]{2}{*}{4} & 2 & Karate 5EC & 1000 & Dizvan & 700 & - & - & 2 \\
\hline & & & & 1000EC & & & & \\
\hline \multirow[t]{2}{*}{5} & 2 & Dizvan & 700 & Karate 5EC & 1000 & - & - & 2 \\
\hline & & 1000EC & & & & & & \\
\hline \multirow[t]{2}{*}{6} & 2 & Dizvan & 700 & Karate 5EC & 1000 & - & - & 2 \\
\hline & & $1000 \mathrm{EC}$ & & & & & & \\
\hline \multirow[t]{2}{*}{7} & 1 & $\begin{array}{c}\text { Cypermethri } \\
n\end{array}$ & 1000 & - & - & - & - & 1 \\
\hline & & 10EC & & & & & & \\
\hline \multirow[t]{2}{*}{8} & 1 & $\begin{array}{c}\text { Cypermethri } \\
\mathrm{n} \\
\end{array}$ & 1000 & - & - & - & - & 1 \\
\hline & & 10EC & & & & & & \\
\hline \multirow[t]{2}{*}{9} & 3 & Best & 1000 & Best & 1000 & Best & 1000 & 3 \\
\hline & & insecticide & & insecticide & & $\begin{array}{c}\text { insecticid } \\
\mathrm{e}\end{array}$ & & \\
\hline 10 & 3 & Karate 5EC & 1000 & Karate 5EC & 1000 & $\begin{array}{c}\text { Karate } \\
\text { 5EC }\end{array}$ & 1000 & 3 \\
\hline \multicolumn{9}{|l|}{$\begin{array}{c}\text { Cowpea/sorghu } \\
\text { m intercrop }\end{array}$} \\
\hline \multicolumn{9}{|l|}{11} \\
\hline \multirow[t]{2}{*}{12} & 2 & Karate 5EC & 1000 & Karate 5EC & 1000 & - & - & 2 \\
\hline & 2 & Dizvan & 700 & Karate 5EC & 1000 & - & - & 2 \\
\hline \multirow[t]{2}{*}{13} & & 1000EC & & & & & & \\
\hline & 2 & $\begin{array}{c}\text { Cypermethri } \\
\mathrm{n} \\
\end{array}$ & 1000 & $\begin{array}{c}\text { Cypermethri } \\
n\end{array}$ & 1000 & - & - & 2 \\
\hline 14 & & $10 \mathrm{EC}$ & & $10 \mathrm{EC}$ & & & & \\
\hline 15 & 2 & Karate 5EC & 1000 & - & - & - & - & 2 \\
\hline 16 & 1 & Karate 5EC & 1000 & - & - & - & - & 4 \\
\hline \multirow[t]{2}{*}{17} & 0 & - & - & - & - & - & - & 2 \\
\hline & 1 & Dizvan & 700 & - & - & - & - & 1 \\
\hline 18 & & 1000EC & & & & & & \\
\hline \multirow[t]{2}{*}{19} & 0 & 0 & - & - & - & - & - & 1 \\
\hline & 1 & Dizvan & 700 & - & - & - & - & 1 \\
\hline \multirow[t]{2}{*}{20} & & 1000EC & & & & & & \\
\hline & 1 & CyperForce & 1000 & - & - & - & & 2 \\
\hline
\end{tabular}


Promotion of Integrated Pest Management (IPM) in Cowpea Production in Fufore Local Government Area, Adamawa State, Nigeria

Table 3.2: Detail of insecticide types and number of sprays and number of weeding in treatment plots of student researcher.

\begin{tabular}{|c|c|c|c|c|c|c|c|c|c|c|}
\hline \multirow{2}{*}{$\begin{array}{c}\text { Plot } \\
\text { No. } \\
\text { Sole } \\
\text { cowpe } \\
\text { a }\end{array}$} & \multirow{2}{*}{$\begin{array}{c}\text { Total } \\
\text { No. of } \\
\text { Sprayin } \\
\text { g }\end{array}$} & \multicolumn{9}{|c|}{ No. of spraying and type of pesticides used } \\
\hline & & $\begin{array}{c}1^{\text {st }} \\
\text { Sprayin } \\
\mathrm{g}\end{array}$ & $\begin{array}{c}\text { Rate/h } \\
\text { a (ml) }\end{array}$ & $\begin{array}{c}2^{\text {nd }} \\
\text { Sprayin } \\
\text { g }\end{array}$ & $\begin{array}{c}\text { Rate/h } \\
\text { a (ml) }\end{array}$ & $\begin{array}{c}3^{\text {rd }} \\
\text { Spraying }\end{array}$ & $\begin{array}{c}\text { Rate/h } \\
\text { a (ml) }\end{array}$ & $\begin{array}{c}4^{\text {th }} \\
\text { Spraying }\end{array}$ & $\begin{array}{l}\text { Rate/h } \\
\text { a (ml) }\end{array}$ & $\begin{array}{c}\text { No. of } \\
\text { weedin } \\
\text { g }\end{array}$ \\
\hline \multirow[t]{2}{*}{1} & 1 & Karate & 1000 & & & & & & & 2 \\
\hline & & $5 E C$ & & & & & & & & \\
\hline \multirow[t]{2}{*}{2} & 3 & $\sqrt{ }$ & 1000 & $\begin{array}{c}\text { Dizvan } \\
\text { 1000EC }\end{array}$ & 700 & $\begin{array}{c}\text { Cyperme } \\
\text { t hrin } \\
10 \mathrm{EC}\end{array}$ & 1000 & & & 2 \\
\hline & & & & $\sqrt{ }$ & & & & & & \\
\hline 3 & 2 & $\sqrt{ }$ & 1000 & $\sqrt{ }$ & 700 & $\begin{array}{c}\text { Cyperme } \\
\text { t hrin } \\
10 \mathrm{EC}\end{array}$ & & & & 2 \\
\hline \multirow[t]{2}{*}{4} & 4 & $\sqrt{ }$ & 1000 & & 700 & Control & 1000 & $\begin{array}{l}\text { Cyper } \\
\text { force }\end{array}$ & 1000 & 2 \\
\hline & & & & Control & & & & Control & & \\
\hline 5 & 0 & Control & & $\begin{array}{c}\text { Karate } \\
\text { 5EC }\end{array}$ & & & & & & 2 \\
\hline \multirow[t]{2}{*}{6} & 2 & $\begin{array}{c}\text { Dizvan } \\
\text { 1000EC }\end{array}$ & 700 & $\sqrt{ }$ & 1000 & $\begin{array}{c}\text { Cyperme } \\
\text { t hrin } \\
10 \mathrm{EC}\end{array}$ & & & & 2 \\
\hline & & $\sqrt{ }$ & & & & Control & & & & \\
\hline \multirow[t]{2}{*}{7} & 3 & & & Control & 1000 & & 1000 & & & 2 \\
\hline & & Control & & & & $\begin{array}{c}\text { Cyperme } \\
\text { t hrin } \\
10 \mathrm{EC}\end{array}$ & & Control & & \\
\hline \multirow[t]{2}{*}{8} & 0 & & & $\begin{array}{c}\text { Karate } \\
\text { 5EC }\end{array}$ & & $\sqrt{ }$ & & & & 2 \\
\hline & & $\begin{array}{c}\text { Dizvan } \\
\text { 1000EC }\end{array}$ & & $\sqrt{ }$ & & $\sqrt{ }$ & & $\begin{array}{c}\text { Cyperforc } \\
\text { e }\end{array}$ & & \\
\hline \multirow[t]{2}{*}{9} & 4 & $\sqrt{ }$ & 700 & $\sqrt{ }$ & 1000 & Control & 1000 & & 1000 & 2 \\
\hline & & $\sqrt{ }$ & & Control & & $\begin{array}{c}\text { Cyperme } \\
\text { t hrin } \\
10 \mathrm{EC}\end{array}$ & & $\sqrt{ }$ & & \\
\hline 10 & 1 & Control & 700 & $\begin{array}{c}\text { Karate } \\
\text { 5EC }\end{array}$ & 1000 & $\sqrt{ }$ & 1000 & $\sqrt{ }$ & 1000 & 2 \\
\hline 11 & 2 & Dizvan & 700 & $\sqrt{ }$ & 1000 & & 1000 & Control & 1000 & 2 \\
\hline 12 & 0 & 1000EC & & & & & & $\sqrt{ }$ & & 2 \\
\hline \multirow[t]{2}{*}{13} & 3 & $\sqrt{ }$ & 700 & & 1000 & $\begin{array}{c}\text { Cyperme } \\
\text { t hrin } \\
10 \mathrm{EC}\end{array}$ & 1000 & & & 2 \\
\hline & & & & $\begin{array}{l}\text { Dizvan } \\
\text { 1000EC }\end{array}$ & & & & $\begin{array}{c}\text { Cypermet } \\
\text { h rin } \\
10 \mathrm{EC}\end{array}$ & & \\
\hline \multirow[t]{2}{*}{14} & 4 & $\sqrt{ }$ & 700 & $\sqrt{ }$ & 1000 & Control & 1000 & & 1000 & 2 \\
\hline & & Karate & & Control & & & & & & \\
\hline 15 & 1 & $5 E C$ & 700 & & & & & & & 2 \\
\hline
\end{tabular}


A. S. Haddabi

\begin{tabular}{|c|c|c|c|c|c|c|c|c|c|c|}
\hline 16 & 3 & $\sqrt{ }$ & 1000 & & 700 & $\begin{array}{c}\text { Cyperme } \\
\text { thrin } \\
10 \mathrm{EC}\end{array}$ & 1000 & & 2 \\
\hline & & Control & & $\begin{array}{c}\text { Dizvan } \\
\text { 1000EC }\end{array}$ & & & & & & \\
\hline 17 & 2 & Karate & 1000 & & 700 & & & & & 2 \\
\hline 18 & 0 & $5 \mathrm{EC}$ & & & & & & & \multicolumn{2}{c|}{$\begin{array}{c}\text { Cyperforc } \\
\mathrm{e}\end{array}$} \\
\hline 19 & 1 & $\sqrt{ }$ & 1000 & & & & & & 2 \\
\hline 20 & 4 & & 1000 & & 700 & & 1000 & & 1000 & 2 \\
\hline
\end{tabular}

In each of the four categories of the treatment plots of the student researcher, one out of the five plots is randomly selected to be left under control, likewise number of treatment of treatments was randomly assigned.

- Ashes were sprinkled on infested stands and was observed to be effective in deterring insect pests populations.

- In the area of reproductive data in cowpea, flowering commenced with improved variety 33 days after planting and forty days after planting with farmers' variety respectively.

\section{RESULT AND DISCUSSION}

\subsection{SOCIO-ECONOMIC CHARACTERISTICS OF THE FARMERS}

\subsubsection{AGE DISTRIBUTION}

The age distribution of the participating farmers as presented in Table 4.1 shows that $10 \%$ of the farmers were within the age range of 20 and below, 30\% were between 21-40 years, while 55\% fell between $41-60$ years and 5\% of them are 60 years and above respectively. This implies that a large proportion of the participating farmers were within the age of 41-60 years.

Table 4.1: Age distribution of participating farmers group

\begin{tabular}{|c|c|c|}
\hline Age (Years) & Frequency & Percentage \\
\hline$<20$ & 2 & 10 \\
$21-40$ & 6 & 30 \\
$41-60$ & 11 & 55 \\
$>60$ & 1 & 5 \\
\hline Total $=$ & 20 & 100 \\
\hline
\end{tabular}

\subsubsection{EDUCATIONAL LEVEL}

The educational level of the farmers group is a key factor in their perception and adoption of IPM approaches of improved farming practices. However, extension services delivery through extension workers and mass media compensated low level of education of the farmers and boosted their attitude towards improved farming technologies. The educational level of the participating farmers showed that $15 \%$ of them had no formal education and the same for those who had adult education. While 5\% received primary education, $40 \%$ had secondary education, and 20\% had National Diploma and 5\% with H.N.D.

Table 4.2: Distribution of Farmers by Education Level

\begin{tabular}{|l|c|c|}
\hline Educational Qualification & Frequency & Percentage \\
\hline Informal education & 3 & 15 \\
Adult education & 3 & 15 \\
Primary education & 1 & 5 \\
SSCE/Certificate & 8 & 40 \\
\hline
\end{tabular}


Promotion of Integrated Pest Management (IPM) in Cowpea Production in Fufore Local Government Area, Adamawa State, Nigeria

\begin{tabular}{|l|c|c|}
\hline National Diploma & 4 & 20 \\
H.N.D. & 1 & 5 \\
\hline Total $=$ & 20 & 100 \\
\hline
\end{tabular}

\subsubsection{FARMING EXPERIENCE}

The farming experience of each of the farmers was an indicator of his expertise in farming. Table 4.3 shows that the majority (45\%) of the participating farmers had 21-30 years of farming experience. Those with 1-10, 11-20, 21$30,31-40$ and $41-50$ years of farming experience respectively constitutes, $25 \%, 20 \%, 45 \%, 5 \%, 5 \%$. The significance of their years of experience indicated their ability to embrace improved innovations and pests identification, application of improved agronomic practices more especially in pest management in their farms could be said to be satisfactory.

Table 4.3: Distribution of Farmers by Farming experience

\begin{tabular}{|l|c|c|}
\hline Farming experience (years) & Frequency & Percentage \\
\hline $1-10$ & 5 & 25 \\
$11-20$ & 4 & 20 \\
$21-30$ & 9 & 45 \\
$31-40$ & 1 & 5 \\
$41-50$ & 1 & 5 \\
\hline Total = & 20 & 100 \\
\hline
\end{tabular}

\subsubsection{HOUSEHOLD SIZE}

The large family size is required to satisfy the labour requirement on the farm. About $70 \%$ of farm-labour in the area was from family sources, supplemented by about 30\% from hired labour.

Table 4.4 shows that $35 \%$ of the farmers had no children, $30 \%$ had family size of $1-5$ children. $20 \%$ had $6-10$ children and 15\% of them had 11-15 children. Therefore the various family sizes means that there is a reasonable supply of family labour for farm operation among the farmers.

Table 4.4: Distribution of family size by Number of Children

\begin{tabular}{|l|c|c|}
\hline No. of Children & Frequency & Percentage \\
\hline 0 & 7 & 35 \\
$1-5$ & 6 & 30 \\
$6-10$ & 3 & 15 \\
$11-15$ & 4 & 20 \\
\hline Total $=$ & 20 & 100 \\
\hline
\end{tabular}

\subsubsection{LAND ACQUISITION/OWNERSHIP}

Land ownership in the area is mostly acquired through inheritance, but farmers who are not endowed with land have access and acquire by sale, gift, loan and lease based on verbal arrangement for payment of rent with farm produce. However, the issue of acquiring land bear a direct effect on farm size and the output as some farmers do not get the desired hectares at desired locations and at the right time. It should also be noted that there is no infringement to farmers in the use of land and access to their farms in the area.

About $80 \%$ of the participating farmers did not own land personally while only $20 \%$ owned land by buying and inheritance. 


\subsubsection{SOURCES OF CAPITAL OF THE FARMERS}

A. S. Haddabi

Twenty percent (20\%) of the farmers obtained fund/capital for cowpea production from the proceeds of their previous harvest. This category of people were full time farmers who engaged into cowpea production persistently, while $10 \%$ of the group combined farming and trading. The majority of them (40\%) were farmers and civil servants. Thirty percent (30\%) of them sourced for funds through loan from their relatives and friends (Table 4.5).

Table 4.5: Distribution of farmers based on source of income

\begin{tabular}{|l|c|c|}
\hline Source of income & Frequency & Percentage \\
\hline Farming only & 4 & 20 \\
Farming and Trading & 2 & 10 \\
Farming and Civil Service & 8 & 40 \\
Loan & 6 & 30 \\
\hline Total = & 20 & 100 \\
\hline
\end{tabular}

\subsubsection{FARM SIZE}

The land area put under cultivation for cowpea production varied among the farmers due to the variation of income and financial status (table 4.7). Each farmer cultivated farm size that was commensurate with his monetary capability. The majority of the farmers (45\%) cultivated less than 1 hectare, 30\% cultivated from 1 to 2 hectares, while $25 \%$ cultivated from 2 to 3 hectares. Following the awareness created by the IPM practices, the farmers pledged to increase their volume of cowpea production as presented in Table 4.6. This fact was through ascertained through focus group discussion.

Table 4.6: Distribution of farmers based on farm size

\begin{tabular}{|l|c|c|}
\hline Farm Size (Ha) & Frequency & Percentage \\
\hline Less than 1 & 9 & 45 \\
$1-2$ & 6 & 30 \\
$2-3$ & 5 & 25 \\
\hline Total = & 20 & 100 \\
\hline
\end{tabular}

\subsubsection{FARM IMPLEMENTS/MODE OF CULTIVATION}

Due to small farm sizes put into cowpea production by majority of the farmers, most of them use local implements and manual operations in farm work. Tractors were used for ploughing/seed bed preparation by only $30 \%$ of the farmers, while $70 \%$ of them used animal traction.

Cutlasses, hoes, axes, sickles etc. were used during site clearance, planting weeding and harvesting of haulms and straws. The majority of the farm operations were carried out by family.

\subsubsection{SOURCES OF SEEDS AND VARIETIES USED}

All the (100\%) farmers used local varieties (farmers' variety known as 'Kannado' i.e, the spreading type) either obtained from previous harvest through mass selection or bought from the open market.

The improved cowpea variety, (Sampea-8) obtained from the Institute for Agricultural Research, Ahmadu Bello University, Zaria was introduced to the farmers for the study alongside the farmers' variety. The performance of the two varieties with respect to their significant difference in tolerance/resistance to insect pests in relation to grains yield was observed. The farmers claimed that they were not aware of the existence of the improved cowpea seeds. However, the farmers were sensitized and motivated by the IPM profit to acquire their improved seeds from A.D.P., Local Government Agricultural Department or reputable agro-input dealers. 
Promotion of Integrated Pest Management (IPM) in Cowpea Production in Fufore Local Government Area, Adamawa State, Nigeria

\subsection{AWARENESS OF RECOMMENDED IPM PRACTICES}

\subsubsection{AWARENESS AND ADOPTION OF RECOMMENDED IPM PRACTICES IN COWPEA PRODUCTION.}

The farmers grow local varieties of cowpea obtained from previous harvest or bought from open market in the previous years. During and after completion of the project research study, participating farmers in the group became aware of the concept and existence of IPM cowpea specific practices, nutritive and economic value of cowpea, the significance of planting improved cowpea variety in relation to pests tolerance/resistance, high yield potentials and early maturity. They also became aware of recommended production practices especially timely planting and storage methods.

Before this intervention farmers assumed that the use of pesticides was the only remedy for reducing pests population and damage to cowpea. Farmers however understood from the IPM promotion research that pesticides application was the last resort, with precautions involving the safe use of pesticides. Also of paramount importance was the farmers' discovery of the relevance of the cultural practices in pest management. Based on the farmers' adoption of the recommended IPM practices during the research study the following were apparent and well noted by the farmers:

- Sit selection:- The site used for the project study was left fallow for four years, with the last cultivated crop being sorghum.

- Improved cowpea variety (Sampea-8) known for its tolerance/resistance to pests was used alongside farmers variety for comparison in yield potentials and performance under pressure of pests attack.

- Wooden perches and short sorghum talks served as a roost to predatory birds which preyed on insect pests as a component of biological control.

- Routine monitoring or observations were made of the farm to identify pest infestation which were removed and instantly buried in the ground.

- Wood ashes were used in dusting infested stands.

- All weeding carried out manually whereby pests were exposed to predators and harsh environmental conditions. This also encouraged biological control processes.

- Insectivorous birds were left undisturbed during and when searching for their preys in the cowpea farms.

- Where necessary, recommended doses of pesticides were applied as necessary.

- Larger pests such as blister beetles and pod sucking bugs and so on were handpicked, and

- Intercropping with short sorghum facilitated the biological influence of predators, discouraged pest prevalence, compared to the higher prevalence of pests on sole cropped plots.

\subsubsection{CRITERIA FOR PEST IDENTIFICATION}

As cowpea is known for high pests attack by different pest species, various ways were used to identify or observe pest attack. Such criteria included poor germination, stunted growth, leaf distortion, premature defoliation and death of seedlings, shedding of flowers and failure for pods to be formed, distortion and discoloration of flowers, webbing of flowers, pods, and leaves, and production of frass on pods. Other signs of pests identification were shrivelling and premature drying of pods, seed and leaf mining, delay in crop maturity.

However, routine field observation for the physical presence of pests on the farm or scouting or vigilance for the pests, formed fundamental criteria for identification.

\subsubsection{COWPEA PESTS AND THEIR MODE OF DAMAGE}

The various types of pests that attack cowpea crop on the farm occurred at different growth stages. The pests identified in the area of study and those that most frequently caused havoc were:- cowpea Aphid (Aphis craccivora), foliage beetle (Ootheca mutabilis), legume pod borer (Maruca vitrata), flower thrips (Megalurothrips sjostedti), blister beetles (Mylabris bipartia), pod sucking bugs (Anoplocnemis curvipes, Riptortus dentipes, Clavigralla spp. and Nezara virudula). The field-to-store pest, cowpea weevil (Callosobruchus maculatus) was also found attacking the cowpea pods in the field.

International Journal of Engineering Technologies and Management Research 
A. S. Haddabi

Table 4.7: Cowpea Pests and their developmental stage and Nature of Damage caused.

\begin{tabular}{|c|c|c|c|}
\hline Pest species & $\begin{array}{ll}\text { Stage } \\
\text { Damage }\end{array}$ & Nature of Damage & $\begin{array}{l}\text { Pest } \\
\text { status }\end{array}$ \\
\hline Cowpea aphid & Adults & $\begin{array}{l}\text { Feed on under surface of young leaves, young stem } \\
\text { tissue and on pods of mature plants }\end{array}$ & Major \\
\hline \multirow[t]{2}{*}{ (Aphis craccivora) } & & $\begin{array}{l}\text { Defoliation by adults and feeding on cowpea roots } \\
\text { seldomly by larvae }\end{array}$ & \\
\hline & & $\begin{array}{l}\text { Feeding in flower buds and flowers, distortion and } \\
\text { discolouring of flowers }\end{array}$ & \\
\hline Foliage beetle & $\begin{array}{l}\text { Larvae and } \\
\text { adults }\end{array}$ & $\begin{array}{l}\text { Feeding on tender parts of stem, penduncles, flower } \\
\text { buds, flowers and buds. }\end{array}$ & Major \\
\hline \multirow[t]{2}{*}{ (Ootheca mutabilis) } & & Feed on cowpea flower & \\
\hline & $\begin{array}{l}\text { Adults and } \\
\text { nymphs }\end{array}$ & & \\
\hline Flower thrips & & & Major \\
\hline (Megalurothrips sjostedti) & Larvae & & \\
\hline Legume Pod Borer & & Suck sap from green pods & Major \\
\hline \multirow[t]{2}{*}{ (Maruca vitrata) } & Adults & " & \\
\hline & & “ & \\
\hline Blister Beetles & & Suck sap from developing pods & Minor \\
\hline \multicolumn{4}{|l|}{$\begin{array}{l}\text { (Mylabris bipartia_and } \mathrm{M} . \\
\text { farquharsoni) }\end{array}$} \\
\hline & & Seed boring & \\
\hline Pod sucking bugs: & Adults & & \\
\hline Anoplocnemis curvipes & Adults & & \\
\hline Riptortus dentipes & Adults and & & Major \\
\hline Clavigralla spp & nymphs & & \\
\hline \multicolumn{4}{|l|}{ Nezara viridula } \\
\hline & $\begin{array}{l}\text { Larvae and } \\
\text { adults }\end{array}$ & & \\
\hline \multicolumn{4}{|l|}{ Cowpea weevil } \\
\hline (Callosobruchus maculatus) & & & Major \\
\hline
\end{tabular}

Apart from the above pests, squirrels were noted for enormous damage to lately planted cowpea at seedling stage, likewise iguanos intensively eats matured pods. Similarly, crickets, Brachytrupes membranaceus was found to feed on young seedlings. Grasshoppers notably prygomapha spp. ate up leaves but not significant.

However, routine field observation for the physical presence of pests on the farm or scouting or vigilance for the pests, form fundamental criteria for identification.

\subsubsection{AWARENESS OF IMPROVED VARIETIES}

Improved cowpea varieties have potential for resistance/tolerance to pests as the focus for future sustained control, particularly to aphids and bruchids. Most of the aphid-resistant cowpea cultivars like IT83S-728-5, IT84S2246-4, IT85D-3577, IT87S-1394 and KVx 426-1. Among the best of these is IT84S-2246 cultivar recommended for release in Nigeria and other countries (Jackai and Adalla, 1997). Others include Sampea-8 and Sampea-9 which are tolerant to aphids, thrips and bruchids (Mohammed F. Ishaku Personal communication).

Other significant advantages of some improved cowpea varieties are early maturity and high grains yield like Sampea-8. The improved varieties were developed by research institutes such as IITA and Institute for Agricultural Research, A.B.U. Zaria.

The farmers claimed that they were not aware that improved cowpea seeds were in existence. However, the farmers were sensitized to acquire improved seeds from the Agricultural Development Programme (ADP) and Local 
Promotion of Integrated Pest Management (IPM) in Cowpea Production in Fufore Local Government Area, Adamawa State, Nigeria

Government Agricultural Department or reputable agro-inputs dealers. The enlightment was achieved through interaction between the farmers and the student.

\subsubsection{USE OF PESTICIDES AS A COMPONENT OF IPM IN COWPEA PRODUCTION.}

The fact that the use of chemicals in pest reduction should generally be the last resort was well appreciated by the farmers. Where such need arose, precautionary measures were taken. During the study, pesticides were used but according to manufacturers' recommendations in terms of products dosage, timing, targeted pest species, handling and use of protective wears, while $20 \%$ of the farmers did not apply any pesticide, $10 \%$ of them applied pesticides three times. 35\% applied only once, and another 35\% applied twice.

For the experimental plots, various insecticides were applied in different regimes to avoid reinfestation and pests' resurgence. Pesticides applied ranged from zero to four times, and for number of applications, plots were selected and treated randomly. Refer details for frequency of insecticides application and the various costs for both farmers and student in table 4.8. The insecticides applied by the student researcher were multhrin 10EC (Cypermethrin 10EC), Karate 5EC, Dizvan 1000EC (DDVP 1000EC) and CyperForce EC. The insecticides applied by the farmers were Best insecticide, CyperForce, DDVP 1000EC and Karate 5EC.

\subsubsection{MOTIVATING FACTORS FOR TRIAL OF IPM PRACTICES.}

The farmers realized the complementary effects of cultural and agronomic practices and less use of recommended conventional pesticides in reduction of pest population below economic injury level. They considered the approach as a welcome development because of its efficacy in pest management, inexpensive and required simple skills. Other reasons included simple biological interaction influenced by nature, less health risk in pesticides use, better quality of produce, less hazard to environment, sustainability and early maturity which resulted in the production of two crops in one season. Furthermore, the approach provided room for long term elimination of key pests and improvement of soil fertility and conditions. Above all, most of the practices involved were indigenous knowledge technologies of farmers.

\subsubsection{STRENGTHENING THE GROUP.}

After completion of the project, the farmers pledge to sustain the group and fully register as a cooperative society. The group elected their management committee and other sub-committees to manage the group and coordinate group activities to achieve the desired objectives. To succeed towards this aim, all members of the group constituted themselves as stakeholders and obliged to all allegiant to the group and discharge their respective responsibilities effectively. The group were strengthened to:

- Attend group meeting regularly

- Contribute funds, pay dues regularly and settle levies for the group to grow stronger.

- Members partake in decision making and participate in group activities.

- Liaise with funding agencies, financial institutions and agricultural establishments for loans, grants and consultations.

- Keep proper records

- Cooperate and procure farm inputs as a group to reduce cost.

The group has been strengthened through the following ways:-

1) Facilitates registration of the group as a cooperative society

2) Encouraged the group in forming management committee to administer the group.

3) Educates the group on significance of group work and unity

4) Sensitized the group to cooperate with extension workers

5) Enlighten the group on importance of income generating activities

6) Assists the group in drafting article of association

Advised the group to be innovative in adoption of improved farming technologies e.g. IPM practices. 


\subsection{YIELD COMPARISON BETWEEN IMPROVED COWPEA AND FARMERS' VARIETY}

\subsubsection{YIELD PERFORMANCE OF IMPROVED VARIETY (SAMPEA-8) AND FARMERS' VARIETY (KANANNADO) OF COWPEA.}

The farmers unanimously observed that the improved variety was higher yielding that the farmer's variety in term of grains. Table 4.8 and 4.9 illustrates the yield comparison between the two varieties.

Table 4.8: Yield and financial value of cowpea and sorghum grains in relation to cropping system and pest management in farmers' and student's plots. ${ }^{* *}$

\begin{tabular}{|c|c|c|c|c|c|c|c|}
\hline $\begin{array}{c}\text { Plot No. } \\
\text { Farmer/Student }\end{array}$ & $\begin{array}{l}\text { Cropping } \\
\text { system }\end{array}$ & $\begin{array}{c}\text { Yield of } \\
\text { cowpea } \\
\text { grain } \\
(\mathrm{kg} / \mathrm{ha})\end{array}$ & $\begin{array}{l}\text { Yield of } \\
\text { sorghum } \\
\text { grain } \\
\text { (kg/ha) }\end{array}$ & $\begin{array}{c}\text { No. of } \\
\text { insecticide } \\
\text { applications }\end{array}$ & $\begin{array}{c}\text { Cost of } \\
\text { insecticide } \\
\text { and } \\
\text { application } \\
\text { (\#) }\end{array}$ & $\begin{array}{c}\text { Financial } \\
\text { value } \\
\text { (cowpea } \\
\text { grains) } \\
\text { (\#) }\end{array}$ & $\begin{array}{l}\text { Financial } \\
\text { value (\#) }\end{array}$ \\
\hline Sole cropped & $\begin{array}{c}\text { Farmer's } \\
\text { Cowpea } \\
\text { Variety } \\
\end{array}$ & $\begin{array}{l}\text { Farmer } \\
\text { Student }\end{array}$ & $\begin{array}{l}\text { Farmer } \\
\text { Student }\end{array}$ & $\begin{array}{l}\text { Farmer } \\
\text { Student }\end{array}$ & $\begin{array}{l}\text { Farmer } \\
\text { Student }\end{array}$ & $\begin{array}{l}\text { Farmer } \\
\text { Student }\end{array}$ & $\begin{array}{l}\text { (sorghum } \\
\text { grains) }\end{array}$ \\
\hline \multirow[t]{2}{*}{1} & " & & & & & & $\begin{array}{c}\text { Sole } \\
\text { cropped }\end{array}$ \\
\hline & “ & $\begin{array}{l}179.5 \\
1640\end{array}$ & $\begin{array}{l}-- \\
--\end{array}$ & 1 & $\begin{array}{l}1440 \\
1280\end{array}$ & $\begin{array}{c}12,924 \\
118,080\end{array}$ & \\
\hline 2 & $"$ & $\begin{array}{l}256.4 \\
1840\end{array}$ & $\begin{array}{l}- \\
--\end{array}$ & 0 & -3840 & $\begin{array}{l}18,460.8 \\
132,480\end{array}$ & $\begin{array}{l}-- \\
--\end{array}$ \\
\hline 3 & “ & $\begin{array}{l}238.5 \\
1720\end{array}$ & $\begin{array}{l}-- \\
--\end{array}$ & 0 & -2560 & $\begin{array}{c}17,172 \\
123,840\end{array}$ & $\begin{array}{l}- \\
--\end{array}$ \\
\hline 4 & $\begin{array}{c}\text { Improved } \\
\text { cowpea } \\
\text { Variety }\end{array}$ & $\begin{array}{l}282.1 \\
1840\end{array}$ & $\begin{array}{l}-- \\
--\end{array}$ & 2 & $\begin{array}{l}2880 \\
5120\end{array}$ & $\begin{array}{l}20,311.2 \\
132,480\end{array}$ & $\begin{array}{l}-- \\
--\end{array}$ \\
\hline 5 & $"$ & $\begin{array}{l}198.7 \\
1600\end{array}$ & $\begin{array}{l}-- \\
--\end{array}$ & $\begin{array}{c}2 \\
\text { Control }\end{array}$ & 2880 & $\begin{array}{l}14,306.4 \\
115,200\end{array}$ & $\begin{array}{l}- \\
--\end{array}$ \\
\hline \multirow[t]{2}{*}{6} & " & & & & & & \\
\hline & “ & $\begin{array}{l}269.2 \\
1440\end{array}$ & $\begin{array}{l}- \\
--\end{array}$ & 2 & $\begin{array}{l}2880 \\
2560\end{array}$ & $\begin{array}{l}19,306.4 \\
103,680\end{array}$ & $\begin{array}{l}- \\
--\end{array}$ \\
\hline 7 & $\begin{array}{c}\text { Improved } \\
\text { cowpea } \\
\text { variety }\end{array}$ & $\begin{array}{l}419.9 \\
1680\end{array}$ & $\begin{array}{l}-- \\
--\end{array}$ & 1 & $\begin{array}{l}1440 \\
3840\end{array}$ & $\begin{array}{c}30,232.8 \\
120,900\end{array}$ & $\begin{array}{l}-- \\
--\end{array}$ \\
\hline 8 & $"$ & $\begin{array}{l}191.0 \\
1760\end{array}$ & $\begin{array}{l}-- \\
--\end{array}$ & $\begin{array}{c}1 \\
\text { Control }\end{array}$ & 1440 & $\begin{array}{c}13,752 \\
126,720\end{array}$ & $\begin{array}{l}-- \\
--\end{array}$ \\
\hline 9 & $"$ & $\begin{array}{l}532.1 \\
2040\end{array}$ & $\begin{array}{l}- \\
--\end{array}$ & 3 & $\begin{array}{l}2320 \\
5120\end{array}$ & $\begin{array}{c}39,311.2 \\
146,880\end{array}$ & $\begin{array}{l}- \\
--\end{array}$ \\
\hline 10 & “ & $\begin{array}{l}230.8 \\
2000\end{array}$ & $\begin{array}{l}-- \\
--\end{array}$ & 3 & $\begin{array}{l}4320 \\
1280\end{array}$ & $\begin{array}{l}16617.6 \\
144,000\end{array}$ & $\begin{array}{l}-- \\
--\end{array}$ \\
\hline $\begin{array}{l}\text { Cowpea/sorghum } \\
\text { intercropped }\end{array}$ & “ & & & & & & \\
\hline
\end{tabular}


Promotion of Integrated Pest Management (IPM) in Cowpea Production in Fufore Local Government Area, Adamawa State, Nigeria

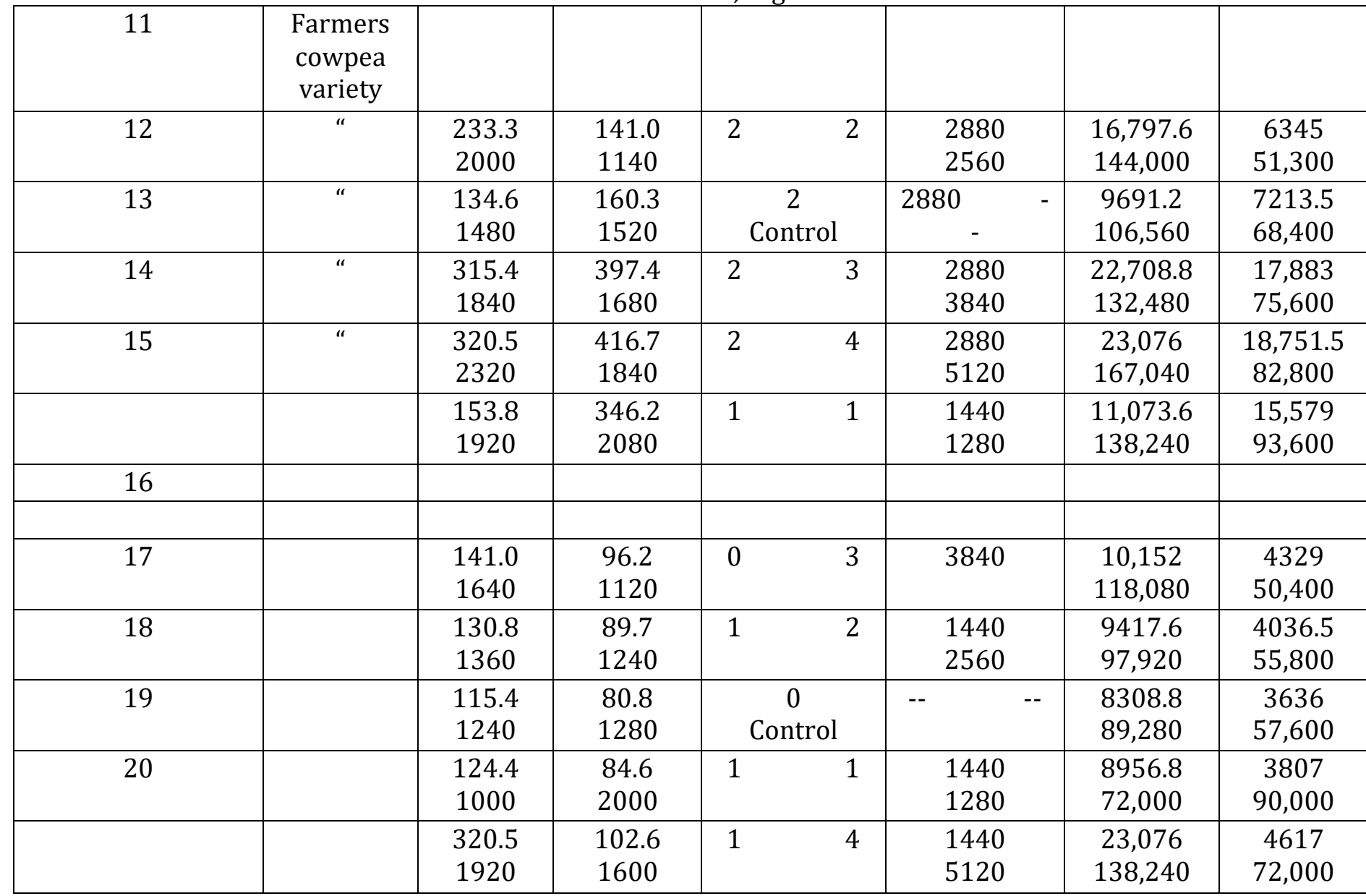

Table 4.9: Yield of cowpea husk and haulm, sorghum husk and straw in relation to cropping system in farmers' and student researcher's plots**

\begin{tabular}{|c|c|c|c|c|c|c|c|c|c|c|c|c|c|c|c|c|}
\hline $\begin{array}{l}\text { Plot } \\
\text { No. } \\
\text { Farm } \\
\text { er/ }\end{array}$ & \multicolumn{2}{|c|}{$\begin{array}{l}\text { Yields of } \\
\text { cowpea } \\
\text { husk } \\
\text { (kg/ha) }\end{array}$} & \multicolumn{2}{|c|}{$\begin{array}{l}\text { Yields of } \\
\text { cowpea } \\
\text { haulm } \\
\text { (kg/ha) }\end{array}$} & \multicolumn{2}{|c|}{$\begin{array}{l}\text { Yields of } \\
\text { sorghum } \\
\text { husk } \\
\text { (kg/ha) }\end{array}$} & \multicolumn{2}{|c|}{$\begin{array}{l}\text { Yields of } \\
\text { sorghum } \\
\text { straw } \\
\text { (kg/ha) }\end{array}$} & \multicolumn{2}{|c|}{$\begin{array}{l}\text { Financial } \\
\text { value of } \\
\text { cowpea } \\
\text { husk ( })\end{array}$} & \multicolumn{2}{|c|}{$\begin{array}{c}\text { Financial } \\
\text { value of } \\
\text { cowpea } \\
\text { haulm (\#) }\end{array}$} & \multicolumn{2}{|c|}{$\begin{array}{l}\text { Financial } \\
\text { value of } \\
\text { sorghum } \\
\text { husk ( })\end{array}$} & \multicolumn{2}{|c|}{$\begin{array}{l}\text { Financial } \\
\text { value of } \\
\text { sorghum } \\
\text { straw (\#) }\end{array}$} \\
\hline $\begin{array}{l}\text { Sole } \\
\text { crop } \\
\text { cowp } \\
\text { ea }\end{array}$ & $\begin{array}{l}\text { Far } \\
\text { mer }\end{array}$ & $\begin{array}{c}\text { Ex } \\
\text { plt } \\
\text { plo } \\
\text { ts }\end{array}$ & $\begin{array}{l}\text { Far } \\
\text { mer }\end{array}$ & $\begin{array}{c}\text { Ex } \\
\text { plt } \\
\text { plo } \\
\text { ts }\end{array}$ & $\begin{array}{l}\text { Far } \\
\text { mer }\end{array}$ & $\begin{array}{c}\text { Ex } \\
\text { plt } \\
\text { plo } \\
\text { ts }\end{array}$ & $\begin{array}{l}\text { Far } \\
\text { mer }\end{array}$ & $\begin{array}{c}\text { Expl } \\
t \\
\text { plot } \\
\mathrm{s}\end{array}$ & $\begin{array}{l}\text { Far } \\
\text { mer }\end{array}$ & $\begin{array}{c}\text { Expl } \\
t \\
\text { plot } \\
\text { s }\end{array}$ & $\begin{array}{l}\text { Far } \\
\text { mer }\end{array}$ & $\begin{array}{c}\text { Expl } \\
t \\
\text { plot } \\
s\end{array}$ & $\begin{array}{l}\text { Far } \\
\text { mer }\end{array}$ & $\begin{array}{c}\text { Ex } \\
\text { plt } \\
\text { plo } \\
\text { ts }\end{array}$ & $\begin{array}{l}\text { Far } \\
\text { mer }\end{array}$ & $\begin{array}{l}\text { Explt } \\
\text { plots }\end{array}$ \\
\hline 1 & 44.9 & $\begin{array}{c}28 \\
0\end{array}$ & $\begin{array}{c}102 . \\
6\end{array}$ & $\begin{array}{c}68 \\
0\end{array}$ & -- & -- & -- & -- & $\begin{array}{c}538 . \\
8\end{array}$ & $\begin{array}{c}336 \\
0\end{array}$ & $\begin{array}{c}205 \\
2\end{array}$ & $\begin{array}{c}13,6 \\
00\end{array}$ & -- & -- & -- & -- \\
\hline 2 & 92.3 & $\begin{array}{c}52 \\
0\end{array}$ & $\begin{array}{c}217 . \\
9\end{array}$ & $\begin{array}{l}10 \\
00\end{array}$ & -- & -- & -- & -- & $\begin{array}{c}110 \\
7.6\end{array}$ & $\begin{array}{c}624 \\
0\end{array}$ & $\begin{array}{c}435 \\
8\end{array}$ & $\begin{array}{c}20,0 \\
00\end{array}$ & -- & -- & -- & -- \\
\hline 3 & 87.2 & $\begin{array}{c}48 \\
0\end{array}$ & $\begin{array}{c}205 . \\
1\end{array}$ & $\begin{array}{c}96 \\
0\end{array}$ & -- & -- & -- & -- & $\begin{array}{c}104 \\
6.4\end{array}$ & $\begin{array}{c}576 \\
0\end{array}$ & $\begin{array}{c}410 \\
2\end{array}$ & $\begin{array}{c}19,2 \\
00\end{array}$ & -- & -- & -- & -- \\
\hline 4 & 57.7 & $\begin{array}{c}40 \\
0\end{array}$ & $\begin{array}{c}179 . \\
5\end{array}$ & $\begin{array}{c}76 \\
0\end{array}$ & -- & -- & -- & -- & $\begin{array}{c}692 . \\
4\end{array}$ & $\begin{array}{c}480 \\
0\end{array}$ & $\begin{array}{c}359 \\
0\end{array}$ & $\begin{array}{c}15,2 \\
00\end{array}$ & -- & -- & -- & -- \\
\hline 5 & 71.8 & $\begin{array}{c}44 \\
0\end{array}$ & $\begin{array}{c}192 . \\
3\end{array}$ & $\begin{array}{c}80 \\
0\end{array}$ & -- & -- & -- & -- & $\begin{array}{c}861 . \\
6\end{array}$ & $\begin{array}{c}528 \\
0\end{array}$ & $\begin{array}{c}384 \\
6\end{array}$ & $\begin{array}{c}16,0 \\
00\end{array}$ & -- & -- & -- & -- \\
\hline 6 & 93.6 & $\begin{array}{c}56 \\
0\end{array}$ & $\begin{array}{c}217 . \\
9\end{array}$ & $\begin{array}{l}10 \\
40\end{array}$ & -- & -- & -- & -- & $\begin{array}{c}112 \\
3.2\end{array}$ & $\begin{array}{c}672 \\
0\end{array}$ & $\begin{array}{c}435 \\
8\end{array}$ & $\begin{array}{c}20,8 \\
00\end{array}$ & -- & -- & -- & -- \\
\hline
\end{tabular}


A. S. Haddabi

\begin{tabular}{|c|c|c|c|c|c|c|c|c|c|c|c|c|c|c|c|c|}
\hline 7 & $\begin{array}{c}103 . \\
8\end{array}$ & $\begin{array}{c}64 \\
0\end{array}$ & $\begin{array}{c}230 . \\
8\end{array}$ & $\begin{array}{l}11 \\
20\end{array}$ & -- & -- & -- & -- & $\begin{array}{c}124 \\
5.6\end{array}$ & $\begin{array}{c}768 \\
0\end{array}$ & $\begin{array}{c}461 \\
6\end{array}$ & $\begin{array}{c}22,4 \\
00 \\
\end{array}$ & -- & -- & -- & -- \\
\hline 8 & 43.6 & $\begin{array}{c}24 \\
0\end{array}$ & 100 & $\begin{array}{c}92 \\
0\end{array}$ & -- & -- & -- & -- & $\begin{array}{c}523 . \\
2\end{array}$ & $\begin{array}{c}288 \\
0\end{array}$ & $\begin{array}{c}200 \\
0\end{array}$ & $\begin{array}{c}18,4 \\
00\end{array}$ & -- & -- & -- & -- \\
\hline 9 & $\begin{array}{c}192 . \\
3\end{array}$ & $\begin{array}{l}13 \\
60\end{array}$ & 500 & $\begin{array}{l}18 \\
00\end{array}$ & -- & -- & -- & -- & $\begin{array}{c}230 \\
7.6\end{array}$ & $\begin{array}{c}16,3 \\
20\end{array}$ & $\begin{array}{c}10,0 \\
00\end{array}$ & $\begin{array}{c}36,0 \\
00\end{array}$ & -- & -- & -- & -- \\
\hline 10 & 83.3 & $\begin{array}{c}44 \\
0\end{array}$ & $\begin{array}{c}198 . \\
7\end{array}$ & $\begin{array}{l}12 \\
40 \\
\end{array}$ & -- & -- & -- & -- & $\begin{array}{c}999 . \\
6\end{array}$ & $\begin{array}{c}528 \\
0\end{array}$ & $\begin{array}{c}397 \\
4\end{array}$ & $\begin{array}{c}24,8 \\
00 \\
\end{array}$ & -- & -- & -- & -- \\
\hline $\begin{array}{c}\text { Cowp } \\
\text { ea/ } \\
\text { Sorgh } \\
\text { um } \\
\text { inter } \\
\text { crop }\end{array}$ & & & & & & & & & & & & & & & & \\
\hline 11 & 87.2 & $\begin{array}{c}48 \\
0\end{array}$ & $\begin{array}{c}224 . \\
4\end{array}$ & $\begin{array}{l}10 \\
80\end{array}$ & 25.6 & $\begin{array}{c}20 \\
0\end{array}$ & $\begin{array}{c}160 \\
2.6\end{array}$ & $\begin{array}{c}720 \\
0\end{array}$ & $\begin{array}{c}104 \\
6.4\end{array}$ & $\begin{array}{c}576 \\
0\end{array}$ & $\begin{array}{c}448 \\
8\end{array}$ & $\begin{array}{c}21,6 \\
00\end{array}$ & $\begin{array}{c}102 . \\
4\end{array}$ & $\begin{array}{c}80 \\
0\end{array}$ & $\begin{array}{c}706 \\
7.5\end{array}$ & $\begin{array}{c}3175 \\
2\end{array}$ \\
\hline 12 & 32.1 & $\begin{array}{c}16 \\
0\end{array}$ & 89.7 & $\begin{array}{c}80 \\
0\end{array}$ & 30.8 & $\begin{array}{c}28 \\
0\end{array}$ & $\begin{array}{c}123 \\
0.8\end{array}$ & $\begin{array}{c}560 \\
0\end{array}$ & $\begin{array}{c}385 . \\
2\end{array}$ & $\begin{array}{c}192 \\
0\end{array}$ & $\begin{array}{c}179 \\
4\end{array}$ & $\begin{array}{c}16,0 \\
00\end{array}$ & $\begin{array}{c}123 . \\
2\end{array}$ & $\begin{array}{l}11 \\
20\end{array}$ & $\begin{array}{c}542 \\
7.8\end{array}$ & $\begin{array}{c}2469 \\
6\end{array}$ \\
\hline 13 & 100 & $\begin{array}{c}60 \\
0\end{array}$ & $\begin{array}{c}216 . \\
7\end{array}$ & $\begin{array}{c}84 \\
0\end{array}$ & 76.9 & $\begin{array}{c}40 \\
0\end{array}$ & $\begin{array}{c}207 \\
6.9\end{array}$ & $\begin{array}{c}960 \\
0\end{array}$ & $\begin{array}{c}120 \\
0\end{array}$ & $\begin{array}{c}720 \\
0\end{array}$ & $\begin{array}{c}433 \\
4\end{array}$ & $\begin{array}{c}16,8 \\
00\end{array}$ & $\begin{array}{c}307 . \\
6\end{array}$ & $\begin{array}{l}16 \\
00\end{array}$ & $\begin{array}{c}915 \\
9.1\end{array}$ & $\begin{array}{c}4233 \\
6\end{array}$ \\
\hline 14 & $\begin{array}{c}102 . \\
6\end{array}$ & $\begin{array}{c}64 \\
0 \\
\end{array}$ & $\begin{array}{c}217 . \\
9\end{array}$ & $\begin{array}{l}13 \\
20 \\
\end{array}$ & 78.2 & $\begin{array}{c}44 \\
0 \\
\end{array}$ & $\begin{array}{c}215 \\
3.8 \\
\end{array}$ & $\begin{array}{c}10,0 \\
00\end{array}$ & $\begin{array}{c}123 \\
1.2 \\
\end{array}$ & $\begin{array}{c}768 \\
0 \\
\end{array}$ & $\begin{array}{c}435 \\
8 \\
\end{array}$ & $\begin{array}{c}26,4 \\
00\end{array}$ & $\begin{array}{c}312 . \\
8\end{array}$ & $\begin{array}{l}17 \\
60 \\
\end{array}$ & $\begin{array}{c}949 \\
8.3 \\
\end{array}$ & $\begin{array}{c}4410 \\
0 \\
\end{array}$ \\
\hline 15 & 48.7 & $\begin{array}{c}32 \\
0\end{array}$ & 500 & $\begin{array}{c}88 \\
0 \\
\end{array}$ & 64.1 & $\begin{array}{c}48 \\
0\end{array}$ & $\begin{array}{c}217 \\
9.5\end{array}$ & $\begin{array}{c}10,2 \\
00\end{array}$ & $\begin{array}{c}584 . \\
4\end{array}$ & $\begin{array}{c}384 \\
0\end{array}$ & $\begin{array}{c}10,0 \\
00\end{array}$ & $\begin{array}{c}17,6 \\
00\end{array}$ & $\begin{array}{c}256 . \\
4\end{array}$ & $\begin{array}{l}19 \\
20\end{array}$ & $\begin{array}{c}961 \\
1.6\end{array}$ & $\begin{array}{c}4498 \\
2 \\
\end{array}$ \\
\hline 16 & 32.1 & $\begin{array}{c}12 \\
0\end{array}$ & $\begin{array}{c}102 . \\
6\end{array}$ & $\begin{array}{c}60 \\
0 \\
\end{array}$ & 17.9 & $\begin{array}{c}12 \\
0\end{array}$ & $\begin{array}{c}108 \\
9.7\end{array}$ & $\begin{array}{c}528 \\
0\end{array}$ & $\begin{array}{c}385 . \\
2\end{array}$ & $\begin{array}{c}144 \\
0\end{array}$ & $\begin{array}{c}205 \\
2\end{array}$ & $\begin{array}{c}12,0 \\
00 \\
\end{array}$ & 71.6 & $\begin{array}{c}48 \\
0\end{array}$ & $\begin{array}{c}480 \\
5.6\end{array}$ & $\begin{array}{c}2328 \\
4.8\end{array}$ \\
\hline 17 & 29.5 & 80 & 84.6 & $\begin{array}{c}52 \\
0\end{array}$ & 12.8 & 80 & $\begin{array}{c}100 \\
0\end{array}$ & $\begin{array}{c}440 \\
0\end{array}$ & 354 & 960 & $\begin{array}{c}169 \\
2\end{array}$ & $\begin{array}{c}10,4 \\
00\end{array}$ & 51.2 & $\begin{array}{c}32 \\
0\end{array}$ & $\begin{array}{c}441 \\
0\end{array}$ & $\begin{array}{c}1940 \\
4\end{array}$ \\
\hline 18 & 24.4 & 80 & 83.3 & $\begin{array}{c}40 \\
0\end{array}$ & 12.8 & 80 & $\begin{array}{c}961 . \\
5\end{array}$ & $\begin{array}{c}380 \\
0\end{array}$ & $\begin{array}{c}292 . \\
8\end{array}$ & 960 & $\begin{array}{c}166 \\
6\end{array}$ & $\begin{array}{c}8,00 \\
0\end{array}$ & 51.2 & $\begin{array}{c}32 \\
0\end{array}$ & $\begin{array}{c}424 \\
0.2\end{array}$ & $\begin{array}{c}1675 \\
8\end{array}$ \\
\hline 19 & 25.6 & 80 & 76.9 & $\begin{array}{c}48 \\
0\end{array}$ & 16.7 & 80 & $\begin{array}{c}974 . \\
4\end{array}$ & $\begin{array}{c}400 \\
0\end{array}$ & $\begin{array}{c}307 . \\
2\end{array}$ & 960 & $\begin{array}{c}153 \\
8\end{array}$ & $\begin{array}{c}9,60 \\
0\end{array}$ & 66.8 & $\begin{array}{c}32 \\
0\end{array}$ & $\begin{array}{c}429 \\
7.1\end{array}$ & $\begin{array}{c}1764 \\
0\end{array}$ \\
\hline 20 & 41.0 & $\begin{array}{c}32 \\
0\end{array}$ & 97.4 & $\begin{array}{c}80 \\
0 \\
\end{array}$ & 17.9 & $\begin{array}{c}12 \\
0\end{array}$ & $\begin{array}{c}158 \\
9.7\end{array}$ & $\begin{array}{c}680 \\
0 \\
\end{array}$ & 492 & $\begin{array}{c}384 \\
0\end{array}$ & $\begin{array}{c}194 \\
8\end{array}$ & $\begin{array}{c}16,0 \\
00\end{array}$ & 71.6 & $\begin{array}{c}48 \\
0 \\
\end{array}$ & $\begin{array}{c}701 \\
0.6 \\
\end{array}$ & $\begin{array}{c}2998 \\
8 \\
\end{array}$ \\
\hline
\end{tabular}

Table 4.10: Yield of cowpea pods and sorghum heads obtained from farmers plots and demonstration/experimental plots (kg/ha).

\begin{tabular}{|c|c|c|c|c|}
\hline \multirow{3}{*}{$\begin{array}{c}\text { Plot No. } \\
\text { (farmer/student) } \\
\text { Sole cowpea }\end{array}$} & \multicolumn{2}{|c|}{ Yield of cowpea (kg/ha) pods } & \multicolumn{2}{|c|}{ Yield of sorghum (kg/ha) heads } \\
\hline & \multicolumn{2}{|c|}{ Plot } & \multicolumn{2}{|c|}{ Demo/expt. } \\
\hline & & & & \\
\hline 1 & 224.4 & 1920 & 0 & 0 \\
\hline 2 & 348.7 & 2360 & 0 & 0 \\
\hline 3 & 325.6 & 2200 & 0 & 0 \\
\hline 4 & 339.7 & 2240 & 0 & 0 \\
\hline 5 & 270.5 & 2040 & 0 & 0 \\
\hline 6 & 362.8 & 2000 & 0 & 0 \\
\hline 7 & 524.4 & 2320 & 0 & 0 \\
\hline 8 & 234.6 & 2000 & 0 & 0 \\
\hline 9 & 724.4 & 3400 & 0 & 0 \\
\hline 10 & 314.1 & 2440 & 0 & 0 \\
\hline
\end{tabular}


Promotion of Integrated Pest Management (IPM) in Cowpea Production in Fufore Local Government Area, Adamawa State, Nigeria

\begin{tabular}{|c|c|c|c|c|}
\hline Cowpea/sorghum intercrop & & & & \\
\hline 11 & 320.5 & 2480 & 166.7 & 1320 \\
\hline 12 & 116.7 & 1640 & 119.0 & 1520 \\
\hline 13 & 415.4 & 2440 & 474.4 & 2080 \\
\hline 14 & 423.1 & 2960 & 494.9 & 2280 \\
\hline 15 & 202.6 & 2240 & 410.3 & 2400 \\
\hline 16 & 173.1 & 1760 & 114.1 & 1240 \\
\hline 17 & 160.3 & 1440 & 102.6 & 1320 \\
\hline 18 & 139.7 & 1320 & 93.6 & 1360 \\
\hline 20 & 150 & 1018 & 101.3 & 2080 \\
\hline & 361.5 & 2240 & 120.5 & 1920 \\
\hline
\end{tabular}

\subsection{PROFITABILITY AND ADVANTAGES OF IPM PRACTICES IN COWPEA PRODUCTION}

The economic gains of cowpea production under IPM compared to farmers' practices is analysed based on yield and their prices.

\subsubsection{COMPARATIVE COST AND RETURNS ANALYSIS BETWEEN IPM AND FARMERS' VARIETY.}

This is achieved by gross margin analysis as presented in Tables 4.11, 4.12, 4, 8 and 4.9. The analysis includes price of cowpea and sorghum grains, cowpea and sorghum husk, and cowpea haulm and sorghum straw at farm gate price.

Table 4.11: Average cost of production of a hectare of cowpea using the farmers' local variety in 2008.

\begin{tabular}{|c|c|c|c|}
\hline Cost item & Quantity & Unit Cost & Total Amount \\
\hline Land clearing & Lumpsum & - & 1,500 \\
\hline Seeds & $18 \mathrm{~kg}$ & $150 / \mathrm{kg}$ & 2,700 \\
\hline Fertilizer & $1 \mathrm{bag}$ & 4,000 & 4,000 \\
\hline Insecticides & 4 liters & $800 / 1$ & 3,200 \\
\hline Seed dressing chemicals & 6 sachets & $100 /$ sachets & 600 \\
\hline Land preparation & Lumpsum & - & 8,000 \\
\hline Planting & Lumpsum & - & 1,500 \\
\hline Manual weeding (1st) & Lumpsum & - & 4,000 \\
\hline Manual weeding ( $\left.2^{\text {nd }}\right)$ & Lumpsum & - & 3,000 \\
\hline Fertilizer application & $1 \mathrm{bag}$ & 300/bag & 300 \\
\hline Application of insecticides & 32 spray loads & 80/load & 2,560 \\
\hline Harvesting & Lumpsum & - & 2,400 \\
\hline Threshing & Lumpsum & - & 2,400 \\
\hline Bags & 18 & 60 & 1,080 \\
\hline Transportation & Lumpsum & - & 2,000 \\
\hline Logistics & 40 trips & 150/trip & 6,000 \\
\hline Total Variable cost (TVC) & & & 45,240 \\
\hline
\end{tabular}

From the above analysis, the farmers averagely operate with a nominal success which is associated with failure to carry out agronomic operations at appropriate time, inability to scare rodents after planting, failure to Replant, non-use of fertilizer, low planting density and inability to regularly monitor pests among the farmers. 
A. S. Haddabi

Table: 4.12: Average cost of production for a hectare of improved variety under IPM in 2008.

\begin{tabular}{|l|c|c|c|}
\hline Cost item & Quantity & Unit Cost & Total Amount \\
\hline Land clearing & Lumpsum & - & 1,500 \\
\hline Seeds & $18 \mathrm{~kg}$ & $150 / \mathrm{kg}$ & 2,700 \\
\hline Fertilizer & $1 \mathrm{bag}$ & 4,000 & 4,000 \\
\hline Insecticides & 4 liters & $800 / \mathrm{l}$ & 3,200 \\
\hline Seed dressing chemicals & 6 sachets & $100 /$ sachets & 600 \\
\hline Land preparation & Lumpsum & - & 8,000 \\
\hline Planting & Lumpsum & - & 1,500 \\
\hline Manual weeding $\left(1^{\text {st }}\right)$ & Lumpsum & - & 4,000 \\
\hline Manual weeding $\left(2^{\text {nd }}\right)$ & Lumpsum & - & 3,000 \\
\hline Fertilizer application & 1 bag & $300 /$ bag & 300 \\
\hline Application of insecticides & 32 spray loads & $80 /$ load & 2,560 \\
\hline Harvesting & Lumpsum & - & 2,400 \\
\hline Threshing & Lumpsum & - & 2,400 \\
\hline Bags & 18 & 60 & 1,080 \\
\hline Transportation & Lumpsum & - & 2,000 \\
\hline Logistics & 40 trips & $150 /$ trip & 6,000 \\
\hline Total Variable cost (TVC) & & & 45,240 \\
\hline
\end{tabular}

1) Gross farm income: (Student)

Determination of the gross margin based on students' practices

- $\quad$ Price of cowpea grains $=$ N123,408

- $\quad$ Price of cowpea husk $=\mathrm{N} 4,944$

- $\quad$ Price of cowpea haulm $=\mathrm{N} 18,040$

- $\quad$ Price of sorghum grains $=$ N69,750

- $\quad$ Price of sorghum husk = N912

- $\quad$ Price of sorghum straw $=\mathrm{N} 28,897.80$

$\mathrm{GFI}=\mathrm{N} 245,951.80$

Gross margin $=$ AGFI - ATVC $=$ N245,951.80 - N45,240 $=$ N200,711.80

2) Gross farm income (GFI): (Farmer)

Determination of the gross margin based on farmers' practices

- $\quad$ Price of cowpea grains $=$ N17,236.80

- $\quad$ Price of cowpea husk $=$ N866.40

- $\quad$ Price of cowpea haulm $=$ N3,840

- $\quad$ Price of sorghum grains $=\mathrm{N} 8,622$

- Price of sorghum husk = N141.60

- $\quad$ Price of sorghum straw $=$ N6,552.80

GFI $=$ N37,259.60

$\therefore$ Gross farm margin = average GFI - average TVC

$=\mathrm{N} 37,259.60-\mathrm{N} 30,360=\mathrm{N} 6,899.60$

With regards to the above analysis of operation by both farmers and the student researcher, it reveals that the IPM approach is profitable especially if carried out appropriately.

The results obtained from the student researcher's IPM demonstration/experimental plots was significantly and economically more profitable and worthy of adoption because the grain achieved was over $300 \%$ than the cost of production while the success recorded by the farmers was just about $18.5 \%$. 
Promotion of Integrated Pest Management (IPM) in Cowpea Production in Fufore Local Government Area,

\subsection{TRAINING AND DEMONSTRATIONS}

Adamawa State, Nigeria

During and after completion of the project, the farmers have learned the various IPM and recommended agronomic practices in cowpea production as carried out by the student and his field supervisors. The farmers harmonized the IPM with their indigenous knowledge of pest control technologies. The farmers and the student actively took part in the participatory research project. The farmers therefore accepted to adopt these practices continuously because they were convinced by the research results based on IPM philosophy.

\subsubsection{TRAINING FARMERS ON IPM PRACTICES THROUGH METHOD DEMONSTRATION}

Some areas of training and demonstration conducted were as follows:-

- Row planting and spacing:- A spacing of $60 \mathrm{~cm} \times 75 \mathrm{~cm}$ was planted; problems of rodents damage necessitated in replanting to fill the gaps.

- Thinning:- Was conducted 1 week after planting leaving 2 seedlings per stand

- Correct use of fertilizer:- The farmers learned how to apply recommended dose of fertilizer 2 weeks after planting by side placement $7 \mathrm{~cm}$ away from the stand.

- Installment of perches:- Perches were erected by farmers to attract predatory birds to feed on insect pests and their formations to enhance biological control.

- Identification of pests:- The farmers adopted observations for identification of pests physically. Some of the identification indicators are presence of pests, defoliation, discolouring of flowers, falling of flowers and leaves, boring of leaves and pods shrinking and shrivelling of flowers and buds, stunted growth, failure of seeds to germinate to some extent.

- Handling of pesticides:- Most of the farmers had poor knowledge of pesticides use, recommended materials in relation to target pest, and potential health and environmental hazards posed by pesticides, Pest population density and intensity of damage that warranted the use of pesticides, proper insecticides dosages and their frequency of use as well as calibration of spray machines and proper time of application were all considered important in IPM decision processes. All were variously imparted to farmers who were very much sensitized on these aspects. Also safe use and proper disposal of pesticides and their containers were also learned by the farmers. It was noted that the farmers did not used proper clothing when handling and applying pesticides, but after proper guidance and sensitization on the dangers of such attitudes, they changed their ways by adhering to the advice.

- Operatio and maintenance of spray equipments:- The farmers used hydraulic knapsack sprayers in application of pesticides. Principles of operation of these equipments, maintenance, time and speed limit during operations were demonstrated and adequately taught.

- Disposal of infested stands: Farmers were oriented on the identification, physical removal of pests and burying pest infested stands.

- Drying cowpea: Drying cowpea grains to the required minimum moisture content for long storage were taught to the farmers.

\subsection{SUSTAINABILITY OF IPM IN COWPEA PRODUCTION IN FUFORE LOCAL GOVERNMENT AREA}

Sustainability of IPM in cowpea production in the study area can be influenced by various factors such as success of IPM trial in terms of yield and profit, reduced cost of production, availability and access to various control strategies, constant enlightenment of farmers by extension workers, availability and access to improved varieties etc.

\subsubsection{MEASURES AVAILABLE FOR SUSTAINABILITY OF THE SUCCESS ACHIEVED BY IPM IN FUFORE LOCAL GOVERNMENT AREA}

- Cultural agronomic farm operations carried out by farmers from significant part of IPM technology

- Improved cowpea varieties resistant/tolerant to pests attack are available in ADP office and reputable inputs dealers for farmers to access

International Journal of Engineering Technologies and Management Research 
A. S. Haddabi

- Wide range of agro-ecosystem in the study area favours biological process of pest control.

\subsubsection{PROBLEMS OF IPM THAT CAN HINDER ADOPTION OF THE TECHNOLOGY IN FUFORE LOCAL GOVERNMENT AREA}

Most IPM activities are expected to be adopted by farmers, take place on their farms and to be supported from many agricultural establishments. Because of lack of coordination at the national levels, state and local government levels, there have been few opportunities to take comprehensive stock of the reasons for the lack of adoption of IPM in Fufore Local Government Area.

The problems that impede adoption of IPM technology among other things include:

- The factors determining the best mix of pest management tactics are not under the control of farmers e.g. quarantine regulations, regulation on cropping practices and controls against migratory pest

- Lack of broad-based public awareness efforts on IPM

- It takes relatively longer time for results of IPM success to prevail.

\subsubsection{REMEDIES TO PROBLEMS HINDERING ADOPTION OF IPM TECHNOLOGY}

1) Biological Pest control strategy is favourably controlled by nature and culturally harnessed by farmers.

2) Good links existing between farmers and extension workers in sharing ideas enhance impartment of knowledge and skills.

\subsubsection{ADOPTION OF IPM APPROACH IN COWPEA PRODUCTION AS FROM YEAR 2009 CROPPING SEASON.}

Though all the farmers have accepted to continue with the IPM practices as from next farming year (2009), but $35 \%$ of the farmers who are at the final stage of their secondary school, and production period coincides with their final examinations will fully adopt in the year 2010 while $65 \%$ will adopt as from 2009.

\section{SUMMARY, CONCLUSION AND RECOMMENDATIONS}

\subsection{SUMMARY}

The research study was undertaken to promote IPM in cowpea production in Fufore Local Government Area. The broad objective of the study is to promote integrated pest management practices in cowpea production in Fufore Local Government Area of Adamawa State, Nigeria and the specific objective is to determine the awareness, among cowpea growers, on the existence of IPM practices specifically in cowpea production, and to encourage and create cowpea IPM awareness among farmers.

In the age distribution, 55\% of the farmers fell within age range of 41-60 years. The age factor was important in the adoption of improved technologies because it indicated the need for farming experience required in the production process.

The educational levels showed that $40 \%$ of the farmers obtained school certificate and only $15 \%$ of them had no formal education. $45 \%$ of the farmers had 21-30 years of farming experience which is an indicator of expertise. $30 \%-35 \%$ of the farmers had family size of 6-7 which means the family size can moderately satisfy the labour requirement on the farm. $80 \%$ of the farmers had no personal land instead they lease land for farming.

The study reveals that the farmers were completely unaware of IPM cowpea specific even though the various cultural agronomic operations of the farmers form good component of the approach and were anxious in putting whose IPM practices into practice with the use of two different varieties. These were improved variety (Sampea-8) and farmers variety.

The improved variety matures earlier and yields higher than the farmers variety. Also yield mostly vary with number of pesticides spray, appropriate cultural operations and variety used.

This result coupled with the impressive performance of the improved variety attract interest from farmers and all of them pledge to adopt IPM practices $(65 \%$ as from 2009 and $35 \%$ as from 2010 because the latter will face their final school certificate examinations in 2009 which coincides with production period). The A.D.P. and local

International Journal of Engineering Technologies and Management Research 
Promotion of Integrated Pest Management (IPM) in Cowpea Production in Fufore Local Government Area, Adamawa State, Nigeria

government agricultural department in the study area are committed for the sustenance of the approach by encouraging and facilitating adoption.

\subsection{CONCLUSION}

The study found out that working with farmers group is very interesting and motivating especially when they are fully committed to an innovation. The farmers in the group are familiar with each other, lives in the same environment which creates opportunities for collective action, mutual understanding and assistance for mobilizing resources for self-sustenance and facilitates sustainability of technologies. Also group work encourages dynamic interaction which facilitates knowledge and ideas sharing, skill acquisition by means of active participation during field demonstrations, and partaking during project planning and implementation which are likely to enhance the project practices due to the social network that drives the diffusion and adoption of the new technology.

The gross margin analysis showed that output from farmers was less profitable. The disparity is because of the keen commitment of the student to provide the required attention to the practices without hesitation contrary to farmers who exercise fear of failure from the beginning because of the drought experienced and late resumption of rains. It was understood and realized that even at later part of the season the improve cowpea variety gives good yield and tolerate pests attack. Cowpea stands a good position in the diet of people in the study area and as source of feed to livestock thereby attracting good price in the market.

There is no doubt that the participating farmers will adopt IPM in cowpea production and other farmers in the study area will put the practices into trial next season. This hope is buttressed by farmers refusing the student to procure more improved cowpea seed from I.A.R. for subsequent use in large hectarages.

\subsection{RECOMMENDATIONS}

With respect to field results on the trial of IPM in cowpea production, some challenges and experiences were gone through which prompted the following recommendations:-

1) It is hereby recommended that the Federal Government of Nigeria should adopt integrated pest management as its crop protection policy in order to curb the excessive use of pesticides leading to health risk, environmental problems, killing of beneficial species, creation of secondary pests and pests resurgence, etc. The reason is that pesticides should only be used as a last resort because it is not sustainable. Therefore application of agronomic cultural practices and facilitation of biological processes can effectively replace pesticides in reduction of pests populations below economic injury levels and these cultural practices are already farmers technology which have been long in existence and least costly, therefore where use of pesticides become necessary, the safest products that are target specific should be used according to manufacturers recommendations just for 2 or 3 spraying at budding, flowering and podding stage or otherwise. Importation of banned and lethal pesticides should be strictly checked by the Government through a regulatory agency.

2) Farmers should be time conscious in carrying out farm operations like early planting, timely weeding, timely harvesting and timely spraying when necessary.

3) Use of farmer field schools or participatory approach should be encouraged by policy makers and extension agencies as an effective instrument for boosting the impact of adopting improved agricultural innovation. This measure can also hasten diffusion of technologies to other farmers group

4) Government should ensure that all necessary inputs are made available to the farmers at the right time and at affordable costs. Distribution of the inputs should be conducted and supervised by government agents, local leaders and farmer's representatives to check antagonistic attitude of middlemen and politicians.

5) Agricultural extension services at all levels should be improved to ensure good working condition for extension agents for effective service delivery and prompt contact with farmers.

6) Adult and non-formal educational programmes should be re-organized to address the problems of low level of education of the farmers to supplement extension in agricultural training programmes.

7) Also farmers should be sensitized on dangers of using highly toxic pesticides and inappropriate equipments. 


\section{A. S. Haddabi}

Highly toxic products can be identified through the products label. Insecticides carries red colour indicator ranging from mild to dark colour. Dark colour indicates severity of toxicity and vice versa, so also a danger sign of human skull and bones means the product is highly toxic. The few educated among the farmers can read products label and understand.

Similarly inappropriate spray equipments e.g. hydraulic knapsack sprayers are identified e.g. when leaking, poor discharge of product solution etc.

8) Government should ensure availability of trained personnel on IPM at all levels, provide adequate infrastructure and enhance good links between research and extension.

9) Sustained funding for suitable training programmes on IPM should be adequately devised and provision of incentive to farmers to boost good technology adoption.

10) Two (2) pesticides application is enough to reduce pests population below economic injury level (in combination with other appropriate agronomic farm operations) to obtain appreciable cowpea yields. Because field experience with student trials reveals just a more nominal difference in yield between 1 and 2 applications, and even an average yield where applied once is better that twice applications, and a little difference between 2 and 3 applications.

\section{SOURCES OF FUNDING}

None.

\section{CONFLICT OF INTEREST}

None.

\section{ACKNOWLEDGMENT}

None.

\section{REFERENCES}

[1] Acquaah, G. (2005) Principles of Crop production-Theory, Techniques and Technology, prentice-Hall, inc., New Delhi, India. 460pp.

[2] Alabi, O.Y., Odebiyi, J.A. and Tamo, M. (2003) "Effect of Host Plant Resistance in some Cowpea (Vigna Unguiculata $\{\mathrm{L}\}$ Walp.) Cultivars on growth and developmental parameters of the flower bud thrips, Megalurothrips sjostedti (trybon)" In Crop protection Journal, vol.23, No.2, February, 2004.pp. 83-87.

[3] Ani, A.O. (2007) Agricultural Extension: A pathway for sustainable Agricultural Development, Apani publications, Kaduna, Nigeria. 179pp.

[4] Annan, B., Schaffers, G.A., Tingey, W.M. and Saxena, K. (1999) "Pattern and rate of within-field Dispersal and Bionomics of the Cowpea Aphid, (Aphis craccivora) on selected cowpea cultivars" Insect science and its application, Herren, H.R. (ed), ICIPE Science press, Kenya. 98 Pp.

[5] Anomymous (2007) Integrated Pest Management, www.iita.org.

[6] Baur, F.J. (1984)" Chemical methods to control insect pests of processed foods' Insect management for food storage and processing, Baur, F.J. (ed), American Association of Cereal chemists, st. Paul, MN, U.S.A. 440pp.

[7] Booker, R.H. (1965) Pests of Cowpea and their control in Northern Nigeria. Bulletin of Entomological Research 55:663-672.

[8] Dent, D. (1993) Insect pest management, CAB international Wallingfood, UK. 604pp.

[9] De Fliert, E.V. and Winarto, Y.T. (2006) "From Technological packages to Ecological principles" LEISA Magazine, special issue, 2006.pp 12-14.

[10] Daxl, R., Kayser lingk, N.V., Klein-Koch, C, Link, R. and Waibel, H. (1994) Integrated Pest Management: guidelines, Deutsche GTZ, Germany. 119pp.

[11] Downham, M.C.A., Hall, D.R., Datinon, B., Dahounto, D., Adetonah, J. and Tanimo, M. (2000) Development of sex pheromone traps for monitoring the legume pod borer (Maruca vitrata f.), www.iita.org/details/cowpeapdf/cowpea-2-3.pdf. 
Promotion of Integrated Pest Management (IPM) in Cowpea Production in Fufore Local Government Area, Adamawa State, Nigeria

[12] Dungum, S.M, Dike, M.C., Adebitan, S.A. and Ogida, J.A. (2005) "Efficacy of some plant materials for the control of cowpea field insect pests at Bauchi Nigeria" Nigerian Journal of Entomology, vol. 22, 205.pp.460-53.

[13] Erbaugh, J.M., Donnermeyer, J. and Amujal, M. (2007) Assessing the impact of farmer field school participation on IPM adoption in Uganda, http://www.aiaee.org/2007/accepted/105.pdf.pp.105-115

[14] Kennedy, D. (1975) Contemporary pest control practices and prospects, vol.1, National Academy of Sciences, Washington, D.C. 506pp.

[15] Kolke, G.V. and Kern, M. (2006) “Chemicals for the poorest-hazard or chance?” Agriculture and Rural Development Magazine, 13, No.1,2006. pp.48-50.

[16] Kochhar, S.L. (1986) Tropical crops: a textbook of economic botany, Macmillan publishers, Delhi, India. 467pp.

[17] Ishaku, M.F. (Personal Communication) Plant Science Department/Institute for Agricultural Research, Ahmadu Bello University, Zaria.

[18] Matthews, G., Wiles, T. and Baleguel, P. (2003) “A survey of pesticide application in Cameroon" Crop protection Journal, vol.22, No.5, June, 2003.pp. 707-708.

[19] Nabirye, J., Nampala, P., Ogenga-latigo, M.W., Kyamanywa, S., Wilson,H., Odeke, V., Iceduna, C. and Adipala, E. (2003) "Farmer-participatory Evaluation of Cowpea integrated pest management Technologies in eastern Uganda “Crop Protection Journal, Vol.22, No.1, February 2003. Pp.31-37.

[20] Ndiaye, M. (2007) Ecology and management of charcoal rot (Macrophomina phaseolina) on cowpea in the sahel, Ph.D thesis, Waginingen University, the Netherlands. 114pp.

[21] Ofuya, T.I. (1995) "Colonization and control of Aphis craccivora by Coccinellid predators in some Resistant and susceptible cowpea varieties in Nigeria" Crop protection Journal, vol.14,No1February 195.pp. 47-50.

[22] Oghiakhe, S. (1995) "Effect of pubescence in cowpea Resistance to the legume pod Borer, Maruca testulalis (Lepidoptera: pyralidae)" Crop protection Journal, vol.14, No.5, August 1995.Pp.379-386.

[23] Ogunbameru, B.O. (2001) Practical Agricultural Communication, Daily Graphics Nig. Ltd, Ibadan, Nigeria. $119 \mathrm{pp}$.

[24] Palm, C.E., Dykstra, W.W., Ferguson, G.R., Hansderry, R., Hayes Jr., W.J., Hazleton, L.W., Horsfall, J.G., Knipling, E.F., Leach, L.D., Lovvorn, R.L. and Swanson, G.A. (1971) Insect pest management and control, Vol.3, National Academy of Sciences, Washinton D.C. 506pp.

[25] Pitan, O.O.R. and Odebiyi, J.A. (1991) "Effect of intra-row spacing of cowpea on pod-Sucking Bugs population and damage in Ibadan, Nigeria" Nigerian Journal of Entomology, vol.19, 2002. Pp.31-39.

[26] Rothschild, G.H.L. (1992) Integrated pest management in Developing countries: Experience and prospects, National Resources Institute, Chatham, United Kingdom. 77pp.

[27] Schuler, B. (2006) "Chemicals Management: what dialogue and training can achieve" Agriculture and Rural Development Magazine, Vol.13 No.1, 2006. pp.57-59.

[28] Sherwood, S., Cole, D. and Murray, D. (2007) “It's time to ban highly hazardous pesticides" LEISA Magazine, Vol.23, No.3, September 2007.pp. 32-33.

[29] Sill Jr., W.H., (1978) The plant protection discipline: problems and possible development strategies, A Halsted press book, john Wiley and Sons, U.S.A. 190pp.

[30] Singh, B.B. (2004) "A plan to apply Technology in the improvement of cowpea productivity and utilization for the benefit of farmers and consumers in Africa” proceedings of a cowpea stakeholders' workshop, $10^{\text {th }}-12^{\text {th }}$ February, 2004. pp.14-15.

[31] Sing, B.B, Mohan, R.D.R, Dashiell, K.E. and Jackai, L.E.N. (1997) Advances in Cowpea Research, IITA Ibadan and Japan international Research Centre for Agricultural Sciences, Tsukuba, Ibaraki, Japan. 375pp.

[32] Sing, S.R. (1990) Insect Pests of tropical food legumes, IITA, John Wiley and Sons Ltd., England. 451pp.

[33] Singh, S.R. and Rachie, K.O. (1985) Cowpea: Research, production and utilization, IITA, John Wiley and sons, Great Britain. 460pp.

[34] Watt, E.E. and de Arraujo, J.P.P. (1988) Cowpea Research in Brazil, IITA/EMBRAPA, Brazil.360pp. 